\title{
Stochastic modelling for virtual engineering of controlled atmosphere storage
}

\section{of fruit}

\author{
Q.Tri Ho ${ }^{1}$, Seppe Rogge ${ }^{1}$, Pieter Verboven ${ }^{1}$, Bert E. Verlinden ${ }^{2}$, Bart M. Nicolai ${ }^{1,2}$ \\ ${ }^{1}$ BIOSYST-MeBioS, KU Leuven, Willem de Croylaan 42, B-3001 Leuven, Belgium. \\ ${ }^{2}$ Flanders Centre of Postharvest Technology, Willem de Croylaan 42, B-3001 Leuven, Belgium. \\ Corresponding author: Quang Tri Ho \\ E-mail: quangtri.ho@biw.kuleuven.be \\ Tel: 32-16-32 0588 fax: 32-16-32 2955
}

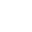

\section{Abstract}

Long term storage of pear fruit requires low temperature and conventionally uses controlled atmosphere (CA) conditions to reduce respiration and consequent quality loss. Sub-optimal storage conditions may lead to physiological disorders and loss of product. Stochastic variability of the properties of fruit introduces uncertainty in storage design and operations and could result in severe quality loss. Taking such variability into account in simulation models for virtual engineering will allow to assess the uncertainty of the process and determine confidence limits for the operation. Gas exchange in pear fruit during controlled atmosphere storage was studied using a continuum diffusion-respiration model, taking into account stochastic variation of the 3D morphology, the diffusivity of oxygen and carbon dioxide and the maximal respiration rate. Different geometries were generated using a statistical shape generation algorithm for 3D morphology, that was automatically incorporated into the gas exchange model. Similarly, tissue diffusivity was computed using a 3D tissue microstructure database. Simulation results showed that internal $\mathrm{O}_{2}$ and $\mathrm{CO}_{2}$ gas profiles in fruit were highly affected by variation of diffusivities, 
24 maximal respiration rate and the 3D morphology of fruit. The model was further used to evaluate 25 incidence to fermentation at different reduced $\mathrm{O}_{2}$ levels of storage condition. The risk of 26 fermentation inside the fruit predicted by the gas exchange model rapidly increased in response 27 to decreasing external $\mathrm{O}_{2}$ levels. The virtual simulation tool confirms that picking time and fruit 28 size are important criteria for proper control of CA storage. While applied here to pear fruit, it 29 can easily be extended to other commodities.

30

31 


\section{Highlights}

33 - A virtual engineering tool for controlled atmosphere storage of fruit is presented

34 A 3D shape generator of fruit is combined with a diffusion-reaction model

35 - The model predicts critical oxygen levels for development of disorders

36 - Random model parameters were incorporated

37 - Fruit size and maturity affect gas concentrations within the fruit the most

38

\section{$39 \quad$ Key words}

40 3D modeling, X-ray micro-CT, mass transfer, respiration, finite element method, biological 41 variability, microstructure.

42

43 


\section{Introduction}

45 Pome fruit are an important fresh food product consumed worldwide. After harvest, fruit are often stored under controlled atmosphere $(\mathrm{CA})$ conditions with reduced $\mathrm{O}_{2}$ and increased $\mathrm{CO}_{2}$

47 levels in combination with a low temperature to extend their commercial storage life. In such conditions, gas exchange inside the fruit affects the respiration process. Bad engineering and

49 control of the storage rooms may result in sub-optimal storage conditions that may lead to physiological disorders and loss of product. In 'Conference' pears (Pyrus communis L.), the

51 physiological disorder is characterised by softening and browning of tissue near the core and is

52 associated with the development of cavities (Franck et al., 2007; Veltman et al., 2003a, 1999)

53 that cause economic losses (Lammertyn et al., 2000; Veltman et al., 2003a; Zerbini and Rizzolo, 54 2002). The main hypothesis for explaining the occurrence of browning is that hypoxia inside the 55 fruit might occur, followed by a switch from respiration to fermentation. The low energy yield of 56 the latter is insufficient for repairing membrane damage, and cell death may result (Herremans et 57 al., 2013a, 2013b; Ho et al., 2011; Lammertyn et al., 2000; Pedreschi et al., 2009; Peppelenbos and Oosterhaven, 1998; Saquet et al., 2003; Streif et al., 2003; Veltman et al., 2003b; Zhou et al., 59 2014). The development of disorders during postharvest ripening and storage of fruit also depends on a range of preharvest factors such as climate conditions. Other factors that have been

61 considered to be influencing the development of the disorder are the size/weight of the fruit and 62 the picking date (Ho et al., 2010a; Lammertyn et al., 2000; Li et al., 2011). Over-mature (late 63 picked) and large fruit have been shown to be more susceptible to core breakdown during storage 64 (Franck et al., 2007; Lammertyn et al., 2000; Verlinden et al., 2002).

65 Computer aided engineering through mathematical modelling of the process has been used as a 66 tool for quantification of the fruit quality during storage (Bosch et al., 2013; Fukuda et al., 2014; 
67 Ho et al., 2013; Pinheiro et al., 2013). As there are no noninvasive measurement techniques

68 available for monitoring respiratory gas concentrations in fruit during CA storage, gas transport

69 models have been used to evaluate gas transport and respiratory gaseous exchange of fruit. We

70 have previously developed models operating at different spatial scales, from the macroscale (Ho

71 et al., 2011, 2008; Lammertyn et al., 2003; Mannapperuma et al., 1991; Verboven et al., 2013) to

72 the microscale level (Ho et al., 2011, 2009; Verboven et al., 2013, 2012) in a multiscale

73 framework and validated them successfully for different apple and pear fruit cultivars (Ho et al.,

74 2010b, 2008). Such modelling has shown that the local gas concentrations and the respiration

75 rate inside fruit differs between cultivars, due to differences in diffusion and respiration

76 properties, shape and size. As a result, optimal storage conditions differ between fruit cultivars

77 (Ho et al., 2013). Because diffusion and respiration properties and fruit shape affect gas

78 exchange in CA storage, variability of these parameters potentially introduces large uncertainty

79 in respiration during storage. Process design should thus account for the effect of variability and

80 predict confidence limits of optimal conditions rather than fixed values (Hertog et al., 2007;

81 Nicolaï et al., 2011; Scheerlinck et al., 2001).

83 The observed variability of diffusion and respiration properties of fruit is large (Ho et al., 2011,

84 2010b). The shape of biological products is often complex, and rather difficult to acquire and

85 describe (Goñi et al., 2008; Mebatsion et al., 2011). In addition, a large variability is found

86 between species and cultivars. We have, however, been able to generate 3D computer models of

87 pome fruit (Rogge et al., 2013). The resulting geometrical models have the same variability as

88 the biological variability in the original biological products. While these 3D geometrical models

89 are directly available as CAD models, numerical modelling of respiratory gas transport 
90 phenomena inside the fruit taking into account 3D geometrical variation of biological products

91 has not been achieved yet.

92 The objective of this contribution was to model the gas exchange in pear fruit taking the effects

93 of biological variability into account. First, the variability distribution of relevant model

94 parameters is determined, including shape, tissue structure and respiration rate. Then, stochastic

95 simulations are used to evaluate the uncertainty of internal respiratory gas concentrations of the

96 fruit and evaluate the consequences for susceptibility to storage disorders under optimal and sub-

97 optimal conditions.

98

99 2. Material and methods

$100 \quad 2.1$ Materials

101 Pears (Pyrus communis 'Conference') were picked from the experimental orchard of the 102 Research Station of Fruit Growing (Velm, Belgium). Fruit was harvested at two stages: in the 103 optimal picking period (on $9^{\text {th }}$ September, 2010) and in the late picking period (on $16^{\text {th }}$ 104 September, 2010). Fruits were cooled and stored according to commercial protocols for a period 105 of 21 days at $-1{ }^{\circ} \mathrm{C}$ followed by controlled atmosphere conditioning $\left(2.5 \mathrm{kPa} \mathrm{O}, 0.7 \mathrm{kPa} \mathrm{CO}_{2},-1\right.$ $106{ }^{\circ} \mathrm{C}$ ) up to the time of the experiment. Picking dates and cooling procedures were according to 107 optimal commercial practices used for long-term storage of fruit.

\section{$2.23 D$ shape generation}

110 An enhanced version of the geometric model generator described in (Rogge et al., 2015) was 111 used to create the required 3D geometric models of pear fruit. The model generator is able to 112 accurately represent all shape features of the 3D outer contour of the pears. The model 
113 generating algorithm that uses a 2D Fourier series expansion was developed based on surface

114 contours extracted form X-ray Computed Tomography images of 66 'Conference' pears (Rogge

115 et al., 2013). After statistical analysis of the obtained descriptors for all pears, new descriptors

116 were generated, representing the studied distributions of descriptors. With the inverse of the

117 shape description method, these new descriptors were transformed into smooth geometries, fit as

118 CAD import for the simulations. The geometries were meshed with Comsol 3.5 (Comsol AB, 119 Stockholm).

120

1212.3 Diffusion-reaction model of gas exchange in pear fruit

122 The diffusion-reaction model of gas exchange that we developed earlier (Ho et al., 2010b, 2008)

123 was used for stochastic simulations in this work. In this approach, tissues are considered to be 124 homogeneous continuum materials. The effect of microstructural features (porosity and 125 tortuosity) on gas transport is incorporated in the apparent value of the tissue properties.

126 Gas concentration gradients are the driving force for gas exchange. The continuum model thus 127 contains diffusion and reaction terms:

$$
\alpha_{i} \frac{\partial C_{i}}{\partial t}=\nabla \cdot D_{i} \nabla C_{i}+R_{i}
$$

129 with $\alpha_{i}$ the gas capacity of the component $i\left(\mathrm{O}_{2}\right.$ and $\left.\mathrm{CO}_{2}\right)$ of the tissue (Ho et al., 2010b), $D_{i}\left(\mathrm{~m}^{2}\right.$ $\left.130 \mathrm{~s}^{-1}\right)$ the apparent diffusion coefficient of the tissue, $R_{i}\left(\mathrm{~mol} \mathrm{~m} \mathrm{~m}^{-3}\right)$ the reaction term of the gas 131 component $i$ related to $\mathrm{O}_{2}$ consumption or $\mathrm{CO}_{2}$ production, $\nabla\left(\mathrm{m}^{-1}\right)$ the gradient operator, and $t$ 132 (s) the time. The time derivative in the left side of Equation (1) represents the concentration 133 changes over time $t$ (s) and becomes zero at equilibrium. Based on preliminary calculations we 134 found that permeation could be neglected. 
135 The gas capacity $\alpha_{i}$ is defined as:

136

$$
\alpha_{i}=\varepsilon+(1-\varepsilon) \cdot R \cdot T \cdot H_{i}=\frac{C_{i, t i s s u e}}{C_{i, g}}
$$

137 where $\varepsilon$ is the porosity of tissue, $C_{i, g}\left(\mathrm{~mol} \mathrm{~m}^{-3}\right)$ and $C_{i, t i s s u e}\left(\mathrm{~mol} \mathrm{~m}^{-3}\right)$ are the concentrations of the 138 gas component $i$ in the gas phase and the tissue, respectively. The concentration of the compound 139 in the liquid phase of fruit tissue normally follows Henry's law represented by the constant $H_{i}$ $140\left(\mathrm{~mol} \mathrm{~m}^{-3} \mathrm{kPa}^{-1}\right) \cdot R\left(8.314 \mathrm{~J} \mathrm{~mol}^{-1} \mathrm{~K}^{-1}\right)$ is the universal gas constant and $T(\mathrm{~K})$ the temperature.

141 A non-competitive inhibition model (Hertog et al., 1998; Ho et al., 2010b; Lammertyn, 2001; 142 Peppelenbos and van't Leven, 1996) is commonly used to describe consumption of $\mathrm{O}_{2}$ by 143 respiration:

$$
R_{\mathrm{O}_{2}}=-\frac{V_{m, \mathrm{O}_{2}} \cdot C_{\mathrm{O}_{2}}}{\left(K_{m, \mathrm{O}_{2}}+C_{\mathrm{O}_{2}}\right) \cdot\left(1+\frac{C_{\mathrm{CO}_{2}}}{K_{m n, \mathrm{CO}}}\right)}
$$

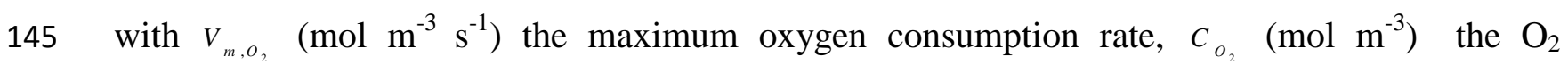
146 concentration, $\left.C_{\mathrm{CO}_{2}}(\mathrm{~mol} \mathrm{~m})^{-3}\right)$ the $\mathrm{CO}_{2}$ concentration, $K_{m, o_{2}}\left(\mathrm{~mol} \mathrm{~m}^{-3}\right)$ the Michaelis-Menten 147 constant for $\mathrm{O}_{2}$ consumption, $K_{m n, \mathrm{CO}_{2}}\left(\mathrm{~mol} \mathrm{~m}^{-3}\right)$ the Michaelis-Menten constant for non148 competitive $\mathrm{CO}_{2}$ inhibition, and $R_{O_{2}}\left(\mathrm{~mol} \mathrm{~m}^{-3} \mathrm{~s}^{-1}\right)$ the $\mathrm{O}_{2}$ consumption rate of the sample.

149 The equation for production rate of $\mathrm{CO}_{2}$ consists of an oxidative respiration part and a 150 fermentative part (Peppelenbos et al., 1996):

$$
R_{\mathrm{CO}_{2}}=-r_{q, o x} \cdot R_{\mathrm{O}_{2}}+\frac{V_{m, f, \mathrm{CO}_{2}}}{\left(1+\frac{C_{\mathrm{O}_{2}}}{K_{m, f, O_{2}}}\right)}
$$


152 with $V_{m, f, \mathrm{CO}_{2}}\left(\mathrm{~mol} \mathrm{~m} \mathrm{~m}^{-3} \mathrm{~s}^{-1}\right)$ the maximum fermentative $\mathrm{CO}_{2}$ production rate, $K_{m, f, o_{2}}\left(\mathrm{~mol} \mathrm{~m} \mathrm{~m}^{-3}\right)$ the

153 Michaelis-Menten constant of $\mathrm{O}_{2}$ inhibition on fermentative $\mathrm{CO}_{2}$ production, $r_{q, o x}$ the respiration 154 quotient at high $\mathrm{O}_{2}$ concentration, and $R_{C_{2}}\left(\mathrm{~mol} \mathrm{~m}^{-3} \mathrm{~s}^{-1}\right)$ the $\mathrm{CO}_{2}$ production rate of the sample.

155 At the fruit surface the following boundary condition is assumed:

156

$$
-D_{i} \frac{\partial C_{i}}{\partial n}=h_{i}\left(C_{i}-C_{i, \infty}\right)
$$

157 with $n$ the outward normal to the surface; the index $\infty$ referring to the gas concentration of the 158 ambient atmosphere; $h_{i}$ the peel permeability for gas $i\left(\mathrm{~m} \mathrm{~s}^{-1}\right)$, which represents the resistance of 159 the peel. Values of model parameters are given in Table 1 with the respective source.

160 The continuum gas exchange model was numerically solved using the finite element method 161 (Comsol 3.5, Comsol AB, Stockholm). Randomly generated 3D pear geometries described in 162 Section 2.3 were employed to calculate the spatial profiles of internal gas concentrations of $\mathrm{O}_{2}$ 163 and $\mathrm{CO}_{2}$ as a result of gas exchange, respiration and fermentation. A finite element mesh with 164 local free mesh-element sizes was generated on the pear geometry. Eqs (1), (3)- (5) were 165 discretised over this mesh and solved using Comsol.

\subsection{Tissue structure and diffusivity}

168 Diffusivity of tissue was calculated from a microscale model (Ho et al., 2011; Verboven et al., 169 2013). Briefly, the microscale diffusion model explicitly accounts for the transport of $\mathrm{O}_{2}$ and $170 \mathrm{CO}_{2}$ in the intercellular space, through the cell wall and plasmalemma into the cytoplasm, and 171 incorporates the actual tissue microstructure as obtained from synchrotron radiation tomography 172 images (Verboven et al., 2008). Six samples with a size of $(0.84 \times 0.84 \times 1.43) \mathrm{mm}^{3}$ were used for 173 the simulations. To determine the diffusivity of $\mathrm{O}_{2}$ and $\mathrm{CO}_{2}$ of a sample, (arbitrary) 
174 concentration differences were applied over the microscale geometry, and the corresponding

175 fluxes were computed by means of the microscale model (Ho et al., 2011; Verboven et al., 176 2013). From the fluxes and the length of the sample, apparent diffusivities were calculated. The

177 computed $\mathrm{O}_{2}$ and $\mathrm{CO}_{2}$ diffusivities with six sample size of $0.84 \times 0.84 \times 1.43 \mathrm{~mm}^{3}$ were equal to $178(2.01 \pm 2.98) \times 10^{-8} \mathrm{~m}^{2} \mathrm{~s}^{-1}$ and $(2.62 \pm 2.97) \times 10^{-8} \mathrm{~m}^{2} \mathrm{~s}^{-1}$, respectively. Variation of diffusivity was 179 found among the samples. Increasing the sample size reduced the variation of the calculated 180 apparent $\mathrm{O}_{2}$ and $\mathrm{CO}_{2}$ diffusivity.

\subsection{Respiration kinetics}

183 A non-competitive inhibition model was used to describe respiration kinetics of fruit tissue. The 184 Michaelis-Menten constant $K_{m}$ value for $\mathrm{O}_{2}$ and $\mathrm{CO}_{2}$ was considered as non-variable (Hertog et 185 al., 1998) and taken from Ho et al. ( 2013) (See Table 1). The maximal respiration rate $V_{m}$ (both 186 the maximal $\mathrm{O}_{2}$ consumption rate and the maximal fermentative $\mathrm{CO}_{2}$ production rate) is a 187 function of the initially available enzyme concentration depending on fruit maturity (Hertog et 188 al., 1998). To determine $V_{m, O_{2}}$ and $V_{m, f, C_{2}}$, respiration rate measurements were carried out at two 189 gas conditions of $21 \mathrm{kPa} \mathrm{O}_{2}, 0 \mathrm{kPa} \mathrm{CO}, 79 \mathrm{kPa} \mathrm{N} \mathrm{N}_{2}$ and $0 \mathrm{kPa} \mathrm{O}_{2}, 0 \mathrm{kPa} \mathrm{CO}, 100 \mathrm{kPa} \mathrm{N}_{2}$, 190 respectively. Briefly, fruit were placed in 1.7 L glass jars (2 fruit per jar) and flushed with two 191 defined gas mixtures for at least 24 hours. For each gas condition, five replications were carried 192 out at $-1{ }^{\circ} \mathrm{C}$ and four replications were carried out at $10^{\circ} \mathrm{C}$ and $20^{\circ} \mathrm{C}$. The jars were closed after 19324 hours. The initial gas composition and pressure in the headspace of jars were measured by 194 means of a gas analyser (Checkmate II, PBI Dansensor, Denmark) and pressure sensor (DPI 142, 195 GE Druck, Germany, accuracy $\pm 0.01 \%$ ). The gas analyser had an accuracy of $\pm 0.1 \%$ and $\pm 0.5 \%$ 196 of the $\mathrm{O}_{2}$ reading and $\mathrm{CO}_{2}$ reading, respectively. The analyser was calibrated against calibrated 
197 mixtures (Air products N.V., Belgium). The headspaces were analysed again after 24 h. The gas

198 percentages were converted to partial pressures by multiplying with the measured total pressure.

199 The gas partial pressure was converted to molar concentration according to the ideal gas law.

200 The $\mathrm{O}_{2}$ consumption and $\mathrm{CO}_{2}$ production rates were calculated from the difference in gas

201 concentration and the time lag between the two measurements and expressed in mole per volume

202 of sample $\left(\mathrm{m}^{3}\right.$ fresh volume of sample) and per unit time (s).

203

$$
R_{i, \text { fruit }}=\frac{\Delta n_{i} \cdot V_{\text {free }}}{\Delta t \cdot V_{\text {fruit }}}
$$

204 where $R_{i, \text { fruit }}\left(\mathrm{mol} \mathrm{m} \mathrm{m}^{-3} \mathrm{~s}^{-1}\right)$ is the $\mathrm{O}_{2}$ consumption $/ \mathrm{CO}_{2}$ production rate of the component $i\left(\mathrm{O}_{2}\right.$ 205 and $\left.\mathrm{CO}_{2}\right) ; \Delta n_{i}\left(\mathrm{~mol} \mathrm{~m}^{-3}\right)$ and $\Delta t(\mathrm{~s})$ are the difference in gas concentration of the component $i$ and 206 the time lag between the two measurements; $V_{\text {fruit }}\left(\mathrm{m}^{3}\right)$ and $V_{\text {air }}\left(\mathrm{m}^{3}\right)$ and are the volume of the 207 fruit and the free air volume of the jar, respectively.

208 In the validation experiments, intact fruits were placed in $1.7 \mathrm{~L}$ glass jars (2 fruit per jar) and 209 flushed with a gas mixture for $24 \mathrm{~h}$. The composition of the latter was $21 \mathrm{kPa} \mathrm{O}_{2}$ and $0 \mathrm{kPa} \mathrm{CO}_{2}$ 210 for the experiments at $10^{\circ} \mathrm{C}$ and $20^{\circ} \mathrm{C}$. Four replicate measurements per gas concentration were 211 carried out. The $\mathrm{O}_{2}$ and $\mathrm{CO}_{2}$ gas partial pressures were monitored with a gas analyser and 212 pressure sensor with time interval of 1day during 10 and 15 days for the experiments at $20^{\circ} \mathrm{C}$ and $21310^{\circ} \mathrm{C}$, respectively. The respiration rate was calculated as mentioned before and compared to the 214 simulation result.

215 
217 Ho et al. (2013) found that $V_{m, o_{2}}, V_{m, f, c o_{2}}$ and the gas diffusivities were the most important

218 parameters beside the shape of fruit. For these parameters, a Monte Carlo analysis was 219 performed to study the effects of biological variability. Hereto we generated 500 random 220 parameter sets and for each set we solved the Eqs (1), (3)- (5). We considered only these 221 parameters to be random and kept all other parameters fixed. For the random number generation 222 of $V_{m, O_{2}}$ and $V_{m, f, \mathrm{CO}_{2}}$ we assumed that these parameters were normally distributed with a standard 223 deviation equal to that obtained from the parameter estimation procedure. Further, $V_{m, o_{2}}$ and $224 V_{m, f, \mathrm{CO}_{2}}$ were assumed to be perfectly correlated (correlation coefficient equal to one) as they 225 share a common pathway (glycolysis).

226 The tissue diffusivities of $\mathrm{O}_{2}$ and $\mathrm{CO}_{2}$ were also assumed to be perfectly correlated as they are all 227 determined by the same tissue microstructure (Ho et al., 2011). In order to generate the apparent 228 diffusivities, a Monte Carlo analysis was carried out. A series of 500 brick-like computational 229 domains with a size of $2.52 \times 2.52 \times 2.86 \mathrm{~mm}^{3}$ was constructed by assembling $18(3 \times 3 \times 2)$ 230 microscale zones. The $\mathrm{O}_{2}$ and $\mathrm{CO}_{2}$ diffusivity of each microscale zone was randomly selected 231 from a set of diffusivity values computed based on 6 different cubical cortex tissue samples with 232 a size of $0.84 \times 0.84 \times 1.43 \mathrm{~mm}^{3}$. The corresponding flux over each of the computational domain 233 was computed from an (arbitrary) concentration difference applied over the domain. The overall 234 apparent diffusivity of each of the 500 computational domains was subsequently calculated from 235 the corresponding flux. A normal distribution was fitted to these values.

236 To account for shape variability, 120 different pear geometries were produced by means of the 237 shape generator. 
240 Monte Carlo simulations were performed for optimal CA storage conditions equal to $2.5 \mathrm{kPa} \mathrm{O}_{2}$, $0.7 \mathrm{kPa} \mathrm{CO} \mathrm{CO}_{2}$ and $-1{ }^{\circ} \mathrm{C}$, for optimally picked and late picked pears. In addition, simulations were

242 performed for a range of different $\mathrm{O}_{2}$ concentrations from 0.5 to $5.5 \mathrm{kPa}$.

243 For each storage condition, 500 random parameter combination sets of diffusivities and maximal 244 respiration rate were randomly chosen. For each set we solved the Eqs (1), (3)-(5) on a pear 245 geometry which was randomly selected from 120 different geometries. The Monte Carlo 246 simulations were carried out by integrating Comsol with Matlab (The Mathworks, Natick, MA) 247 using scripts programmed in the Matlab environment to perform the Monte Carlo simulations in 248 an automated way. In short, the 3D unstructured triangulated surface of a pear geometry was 249 imported into Comsol using CAD import module and the STL file format. A corresponding 250 volumetric geometry was reconstructed from the 3D unstructured triangulated surface and saved 251 as a geometry object with Comsol Multiphysic text file format (*.mphtxt). In each Monte Carlo 252 run for a particular storage condition, the 3D geometry object was randomly generated using the 253 geometrical model generator as described before and imported in Matlab with a script. A finite 254 element mesh was generated from the pear geometry using a default mesh generator function of 255 Comsol. Random parameter values for Eqs (1) and (3)-(5) where generated based on their 256 normal distribution function as described before. The model was then solved for steady state 257 conditions. Finally, the $\mathrm{O}_{2}$ and $\mathrm{CO}_{2}$ partial pressure profiles of Monte Carlo each run were 258 computed from the solution. For each storage condition, the run time for the Monte Carlo 259 simulation with 500 runs was about 4000 to 7000 s on a DUAL CPU Xeon X5650, 48 GB RAM.

260 From the simulations, the internal $\mathrm{O}_{2}$ and $\mathrm{CO}_{2}$ profiles of each fruit were obtained and the 261 minimal value of $\mathrm{O}_{2}\left(C_{O_{2}, \text { min }}\right)$ was determined. This value was compared to the critical $\mathrm{O}_{2}$ level 
262 below which fermentation dominates and disorder development was likely to occur. The critical

$263 \mathrm{O}_{2}$ level $C_{O_{2}}^{*}(\mathrm{kPa})$ was defined as the critical $\mathrm{O}_{2}$ level of tissue where the ATP production rate

264 due to the oxidative respiration is equal to maximal ATP production rate by fermentation. In

265 other words, it is the $\mathrm{O}_{2}$ concentration where the ATP production by oxidative respiration

266 dominates the ATP production over that by fermentation (Ho et al., 2013).

$267 \quad C_{O_{2}}^{*}=\frac{f_{f} \cdot V_{m, f, C O_{2}} \cdot K_{m, O_{2}}}{f_{o} \cdot V_{m, O_{2}} \cdot r_{q, o x}-f_{f} \cdot V_{m, f, C O_{2}}}$

268 where $f_{o}(=6.33)$ and $f_{f}(=1)$ are the stoichiometric coefficients of the ATP production due to the 269 oxidative respiration and the fermentation, respectively (Ho et al., 2013). Since $V_{m, O_{2}}$ and $V_{m, f, \mathrm{CO}_{2}}$

270 were assumed to be perfectly correlated (correlation coefficient equal to one) as they share a 271 common pathway (glycolysis), $C_{O_{2}}^{*}$ in Eq. (6) was not sensitive to variations of these parameters 272 either and could be considered as relatively stable.

273

274 3. Results

2753.1 Random pear geometries

276 Some random shapes produced by the shape generator are shown in Fig. 1a. As a result of the 277 chosen shape description method, the geometries contain some asymmetric, local shape features, 278 that are also observed in real fruit. The histogram in Fig. 1b shows the spread of volumes of the 279 generated geometric models.

280

2813.2 Random $\mathrm{O}_{2}$ and $\mathrm{CO}_{2}$ diffusivities and maximal respiration rate 
282 The gas diffusivity of fruit tissue is directly related to its micro-structure (Ho et al., 2011). Fig.

$2832 \mathrm{a}$ shows the simulated $\mathrm{O}_{2}$ concentration distribution in the intercellular space of a typical 284 parenchyma cortex sample using the microscale gas exchange model. The simulated gas 285 concentrations in the small samples were significantly non uniform and depended to a large 286 extent on the void distribution of the tissue sample. The distribution of the apparent diffusivity of $287 \mathrm{O}_{2}$ and $\mathrm{CO}_{2}$ is shown in Fig. $2 \mathrm{~b} \& 2$ c. The standard deviation of the tissue diffusivity of $\mathrm{O}_{2}$ and $288 \mathrm{CO}_{2}$ was, respectively, between $29 \%$ and $16 \%$ of their mean value. Because the microstructure 289 of optimally and late picked fruit is not different (Verboven et al., 2008), the diffusivity did not 290 depend on maturity.

$291 V_{m, O_{2}}$ and $V_{m, f, \mathrm{CO}_{2}}$ are likely to be proportional to the initially available enzyme concentration 292 (Hertog et al., 1998), and, hence, depend on fruit maturity. The measured $V_{m, o_{2}}$ and $V_{m, f, \mathrm{CO}_{2}}$ of 293 optimally picked pears were $(1.85 \pm 0.14) \times 10^{-5} \mathrm{~mol} \mathrm{~m}^{-3} \mathrm{~s}^{-1}$ and $(1.78 \pm 0.17) \times 10^{-5} \mathrm{~mol} \mathrm{~m}^{-3} \mathrm{~s}^{-1}$, 294 respectively. Histograms of randomly generated $V_{m, o_{2}}$ and $V_{m, f, c o_{2}}$ values are shown in Fig. 2d \& 2952 e.

296

2973.3 Validation of the macroscale model

298 The macroscale model was validated by comparing simulated values with measurements of 299 overall fruit respiration rates at $10^{\circ} \mathrm{C}$ and $20^{\circ} \mathrm{C}$ (Fig. 3) of fruit that were not used for the model 300 calibration. The model used the maximal respiration rate $V_{m}$ (maximum $\mathrm{O}_{2}$ consumption and 301 maximum $\mathrm{CO}_{2}$ production rates) obtained from measurements (see Table 1). Clearly, the model 302 agreed well with the measured values and captured the characteristics of the respiratory response 303 of intact fruit to $\mathrm{O}_{2}$ availability. The $\mathrm{O}_{2}$ concentration at which the $\mathrm{O}_{2}$ consumption rate 
304 decreased to half its maximal value was equal to $1.8 \mathrm{kPa}$ and $4.8 \mathrm{kPa}$ at $10^{\circ} \mathrm{C}$ and $20^{\circ} \mathrm{C}$, 305 respectively.

3063.4 Internal gas concentration profiles in CA condition

307 Pear fruit is a biological material and is inherently affected by biological variation. Stochastic 308 simulation results of the $\mathrm{O}_{2}$ and $\mathrm{CO}_{2}$ distribution inside different fruit are shown in Fig. 4. Due to 309 the diffusion resistance of the cortex tissue, significant concentration gradients were established 310 inside the pear. A decrease of the $\mathrm{O}_{2}$ partial pressure and an increase of the $\mathrm{CO}_{2}$ partial pressure 311 towards the center of the fruit were observed. The concentration gradient in the cortex was steep 312 in pear fruit having a high maximal respiration rate, large volume and low diffusivity. 313 Histograms of the predicted $C_{O_{2} \text {, min }}$ for two storage $\mathrm{O}_{2}$ partial pressures computed with Monte

314 Carlo simulations at $-1{ }^{\circ} \mathrm{C}$ are shown in Fig. 5. At a commercial storage $\mathrm{O}_{2}$ partial pressure of 2.5 $315 \mathrm{kPa}$, the variation of $C_{O_{2}, \mathrm{~min}}$ of optimally picked pear was considerable, with internal 316 concentrations as low as $0.5 \mathrm{kPa}$ (See Fig. 5b). In late picked pear, even lower values were found 317 (Fig. 5d). At storage oxygen partial pressures of $0.5 \mathrm{kPa}$, the internal oxygen concentration 318 dropped below $0.1 \mathrm{kPa}($ Fig. $5 \mathrm{a} \& \mathrm{c})$.

$3203.5 \mathrm{O}_{2}$ concentration in the fruit in response to the atmospheric $\mathrm{O}_{2}$ level of low temperature CA 321 storage

322 The model was applied to compute the smallest $\mathrm{O}_{2}\left(C_{O_{2}, \mathrm{~min}}\right)$ partial pressure inside the fruit for a 323 range of different storage $\mathrm{O}_{2}$ partial pressures. For each storage condition, 500 Monte Carlo 324 simulations were carried out for variable diffusivities, maximal respiration rate $V_{m}$ and fruit 325 shape. The calculated critical $\mathrm{O}_{2}$ level $C_{\mathrm{O}_{2}}^{*}$ was $3.81 \times 10^{-2} \mathrm{kPa}$ for optimally picked fruit. The 
326 predicted $C_{\mathrm{O}_{2} \text {, min }}$ was then compared to $C_{\mathrm{O}_{2}}^{*}$ to evaluate whether fermentation due to hypoxia

327 would occur inside the fruit. The computed $C_{O_{2}, \min }$ is shown in Fig. 5e for optimally picked fruit

328 as a function of the $\mathrm{O}_{2}$ partial pressure of the storage atmosphere at $-1{ }^{\circ} \mathrm{C}$. At $2.5 \mathrm{kPa} \mathrm{O}_{2}, C_{O_{2} \text {, min }}$

329 was mostly larger than $C_{O_{2}}^{*}$ indicating sufficient energy supply for maintaining cell integrity.

330 However, the risk of fermentation inside pear fruit increased at a reduced $\mathrm{O}_{2}$ level of $0.5 \mathrm{kPa}$.

331

3323.6 Effect of picking time on the risk of fermentation during CA storage

333 Pear fruit is more sensitive to storage disorders when it is harvested late (Lammertyn et al., 334 2000). In this study late picking was 7 days after the optimal picking time. The measured $V_{m, o_{2}}$ 335 and $V_{m, f, \mathrm{CO}_{2}}$ of the late picked pear at $-1{ }^{\circ} \mathrm{C}$ were $(2.32 \pm 0.41) \times 10^{-5} \mathrm{~mol} \mathrm{~m}^{-3} \mathrm{~s}^{-1}$ and $336(1.90 \pm 0.49) \times 10^{-5} \mathrm{~mol} \mathrm{~m} \mathrm{~m}^{-3} \mathrm{~s}^{-1}$, respectively. We assumed that picking date would not have an 337 effect on fruit size because in a typical harvest large fruit are picked first and small fruit are left 338 on the tree to further grow and mature and thus to be picked at a later stage.

339 The late picked pear thus had a higher maximal respiration rate than the pear picked at the 340 optimal picking time, while the tissue microstructure and thus diffusivity was the same. The 341 simulation results showed that the minimal $\mathrm{O}_{2}$ concentration for the optimal picked pears was 342 larger than that of late picked pears. At $2.5 \mathrm{kPa} \mathrm{O}_{2}$, the predicted $C_{\mathrm{O}_{2}, \mathrm{~min}}$ of the optimally picked 343 and the late picked pears was $(1.42 \pm 0.22) \mathrm{kPa}$ and $(1.16 \pm 0.30) \mathrm{kPa}$, respectively (Fig. 5b \& 5d).

344 At a very low $\mathrm{O}_{2}$ concentration of $0.5 \mathrm{kPa}$, the predicted $C_{o_{2}, \mathrm{~min}}$ of the optimally and late picked 345 pears was $(0.048 \pm 0.023) \mathrm{kPa}$ and $(0.028 \pm 0.019) \mathrm{kPa}$, respectively (Fig. 5a \& 5c). Hence, late 346 picked pear are clearly more susceptible to fermentation during CA storage than optimally 
347 picked pear. The predicted $C_{O_{2}, \mathrm{~min}}$ for late pick pear as a function of the storage $\mathrm{O}_{2}$ partial 348 pressure at $-1{ }^{\circ} \mathrm{C}$ is shown in Fig. 5f. The increasing respiration rate due to late picking shifts the 349 predicted $C_{\mathrm{O}_{2}, \mathrm{~min}}$ curves towards the bottom left in the figure compared to Fig. 5e.

350

3513.7 Incidence of fermentation and browning disorder

352 The critical $\mathrm{O}_{2}$ level $C_{O_{2}}^{*}$ can be interpreted with respect to the parameters of the respiration and 353 fermentation kinetics (Ho et al., 2013). We assumed that if the local $\mathrm{O}_{2}$ level of pear fruit was 354 lower than $C_{\mathrm{O}_{2}}^{*}$, fermentation due to hypoxia would be likely to occur. The probability of 355 fermentation inside pear fruit was thus calculated for a set of 500 stochastic simulations for each 356 condition. The results are shown in Fig. 6. The occurrence of fermentation was high at $0.5 \mathrm{kPa}$ $357 \mathrm{O}_{2}(35.8 \%$ and $74 \%$ for optimally and late picked pears, respectively) but rapidly decreased 358 when the ambient $\mathrm{O}_{2}$ level increases.

359 To compare these results to previous experimental data, a logistic regression model proposed by 360 Verlinden et al. (2002) was used to predict the incidence of browning disorder at different $\mathrm{O}_{2}$ 361 levels. The results are shown in Fig. 6b. At a commercial storage $\mathrm{O}_{2}$ partial pressure of $2.5 \mathrm{kPa}$, 362 the predicted incidence of storage disorder was indeed low. At a very low storage $\mathrm{O}_{2}$ partial 363 pressure of $0.5 \mathrm{kPa}$, the predicted incidence of browning disorder for the optimally and the late 364 picked pears rapidly increased with storage periods from 4 to 36 weeks. Both models show that 365 the probability of fermentation and browning disorder in pear fruit is high when the $\mathrm{O}_{2}$ partial 366 pressure was $0.5 \mathrm{kPa}$ but rapidly reduced when the $\mathrm{O}_{2}$ partial pressure increased to $2.5 \mathrm{kPa}$. 
370 Simulations were carried out for different fruit volumes in $\mathrm{CA}\left(2.5 \mathrm{kPa} \mathrm{O}_{2}, 0.7 \mathrm{kPa} \mathrm{CO}_{2}\right)$.

371 Histograms of $C_{O_{2}, \text { min }}$ for different fruit volumes with random diffusion and respiration

372 parameters are shown in Fig. 7. Clearly, the risk of fermentation is high for large and late picked

373 fruit when they are stored in CA, for which the distribution considerably shifts towards the left.

374 The results show that increasing the fruit size reduced $C_{O_{2}, \mathrm{~min}}$ and, hence, increased the risk of 375 fermentation.

377 4. Discussion

378 Transport phenomena are important but complex processes in food process and preservation 379 operations. Mathematical modeling serves to improve our understanding of the phenomena, and, 380 more importantly, for designing and optimizing food processes (Datta, 2008; Feyissa et al., 2012; 381 Ho et al., 2013; Perrot et al., 2011; Torrez Irigoyen et al., 2014) in a virtual way by simulation. 382 As we demonstrated here for controlled atmosphere storage of pear fruit, such an approach must 383 account for the complex and variable structure, shape, size and physiological properties of the 384 food through stochastic simulation techniques (Hertog et al., 2007; Rogge et al., 2013; 385 Scheerlinck et al., 2001; Serment-Moreno et al., 2015). In this way, risks can be better evaluated 386 raising confidence in simulation approaches by the food industry.

387 The $\mathrm{O}_{2}$ diffusivity in pear cortex tissue for different batches of pear has been shown to vary from $3882.8 \times 10^{-10} \mathrm{~m}^{2} \mathrm{~s}^{-1}$ to $5.63 \times 10^{-10} \mathrm{~m}^{2} \mathrm{~s}^{-1}$ (Ho et al., 2009, 2006). Schotsmans et al.(2003) found a 389 value of $(4.3 \pm 1.7) \times 10^{-10} \mathrm{~m}^{2} \mathrm{~s}^{-1}$ for the $\mathrm{O}_{2}$ diffusivity of pear cortex tissue while the $\mathrm{O}_{2}$ diffusivity 390 of fleshy tissue reported by Lammertyn et al. (2001) was $1.71 \times 10^{-9} \mathrm{~m}^{2} \mathrm{~s}^{-1}$. The $\mathrm{CO}_{2}$ diffusivity of 
391 pear cortex tissue has been found to range from $1.7 \times 10^{-9}$ to $5.32 \times 10^{-9}$ (Ho et al., 2009, 2006;

392 Schotsmans et al., 2003). The apparent diffusivities computed from the microscale model were

393 thus one order of magnitude larger than previously measured values. This is likely due to the fact

394 that most reported measurements of diffusion properties of pear cortex tissue involved disk

395 shaped tissue samples. Cutting of the sample will cause leaking of the cytoplasm into the

396 micropores by capillary action that is difficult to avoid. Because oxygen diffusion is much faster

397 in gas than in liquid, the tissue diffusivity may thus be underestimated considerably. We verified

398 this hypothesis by showing that, based on simulations with blocked pores, leaking of the cellular

399 liquid into the micropores decreased the effective tissue gas diffusivity considerably

400 (unpublished results). For more porous fruit such as apple, pore leakage does not occur to the

401 same extent and it has been shown that measurement agree with the model predictions (Ho et al.,

402 2011).

403 Fruit shape, maximal respiration rate and diffusivities are the most important parameters 404 affecting the $\mathrm{O}_{2}$ and $\mathrm{CO}_{2}$ profiles inside the fruit (Ho et al., 2013). For 'Conference' pear studied 405 here, the fruit volume varied up to $57 \%$ of its mean value. Similarly, the $\mathrm{O}_{2}$ and $\mathrm{CO}_{2}$ diffusivities 406 of tissue had standard deviations of $29 \%$ and $16 \%$ of their mean value, respectively. We found 407 that the maximal respiration rate was less variable than shape and diffusivity. The standard 408 deviation of maximal respiration rate ranged from $8 \%$ to $18 \%$ of its mean value. This variation 409 had, however, a large impact on the $\mathrm{O}_{2}$ and $\mathrm{CO}_{2}$ concentration profiles and occurrence of 410 fermentation inside fruit during storage. At low $\mathrm{O}_{2}$ condition $(<1 \mathrm{kPa})$, a high incidence of 411 fermentation was predicted and this may cause physiological disorders.

412 These results have implications for novel CA approaches such as dynamic CA (DCA). In DCA, 413 the oxygen concentration in the air-tight storage room is allowed to decrease (by fruit 
414 respiration) well below $1 \mathrm{kPa}$ until the bulk of fruit produces a response signal that indicates that

415 the fruit switches to fermentation, upon which the oxygen concentration is increased by the

416 control system. Several methods have been proposed to measure the fermentation threshold

417 signal (Delele et al., 2013; Gasser et al., 2008; Prange et al., 2011; Veltman et al., 2003b).

418 Evidently from the current analysis, storage at low oxygen is more critical and accurate control is

419 required. Because the DCA control signal holds for the complete fruit load in the room (several 420 hundreds of tons), it is important to mimimize the variability in storage. From the current results,

421 it can be advised that, for DCA, variation of fruit size should be minimized (e.g., by presorting)

422 and batches from different sources and picking dates should be avoided (as these increase the

423 variability of respiration rates).

424 The critical oxygen level $C_{O_{2}}^{*}$ can be interpreted with respect to the parameters of the respiration 425 and fermentation kinetics (Ho et al., 2013). The value of $C_{\mathrm{O}_{2}}^{*}$ for pear at $-1{ }^{\circ} \mathrm{C}$ in this study was $4263.81 \times 10^{-2} \mathrm{kPa}$, which is in the order of magnitude of values found for apple $\left(5.64 \times 10^{-2}\right.$ to $4276.71 \times 10^{-2} \mathrm{kPa}$ Ho et al., 2013). The obtained value (equivalent to $0.8 \mu \mathrm{M}$ in liquid) is 428 approaching the range of the $K_{m}$ of cytochrome $c$ oxidase, the terminal oxidase in plant 429 respiration, which has been measured in artificial media $(0.10-0.12 \mu \mathrm{M}$, Rawsthorne and Larue, $4301986 ; 1 \mu \mathrm{M}$, Taiz and Zeiger, 1993; $0.14 \mu \mathrm{M}$, Millar et al., 1994). The onset of fruit ripening 431 resulted in an increase of the metabolic process and initiated senescence (Masia, 2003). 432 Respiration is the main reason for the decrease of the $\mathrm{O}_{2}$ concentration in the fruit. It is affected 433 by the maturity stage of fruit (Bulens et al., 2012). Late picked fruit was shown to have a high 434 respiration rate (Franck et al., 2007; Streif et al., 2003). Our simulations predict that late picked 435 fruit may be susceptible to fermentation during CA storage because of their high maximal 
436 respiration rate. The occurrence of browning disorder has been shown to be rather non-uniform

437 in a whole batch (Lammertyn et al., 2000; Verlinden et al., 2002): some fruit may have the

438 disorder and other not, and the extent of the defects varies among fruit. Modelling of browning

439 disorder has been studied by means of a black box logistic regression model (Lammertyn et al.,

440 2000; Verlinden et al., 2002). This model predicted a high incidence of browning disorder at an

$441 \mathrm{O}_{2}$ level of $0.5 \mathrm{kPa}$ but a low incidence at a commercial storage $\mathrm{O}_{2}$ level of $2.5 \mathrm{kPa}$. We found

442 similar trends in the occurrence of fermentation inside the fruit using a physical modeling 443 approach.

444

445 5. Conclusions

446 Gas exchange in pear fruit was studied using a continuum model taking into account random 447 variation of diffusivities, maximal respiration rate and the 3D morphology of fruit. We created 448 different 3D geometries to account for biological variation of fruit shape using a geometric 449 model generation algorithm. The model predicted that the $\mathrm{O}_{2}$ and $\mathrm{CO}_{2}$ gas profiles inside the 450 fruit were highly impacted by the $\mathrm{O}_{2}$ and $\mathrm{CO}_{2}$ diffusivity, the maximal respiration rate and the $4513 \mathrm{D}$ morphology of fruit. We have thus shown that the model can be effectively used to predict 452 gas exchange behavior and to analyse the incidence of fermentation at reduced $\mathrm{O}_{2}$ levels during 453 controlled atmosphere storage. Our model predicted that the fermentation inside the fruit would 454 rapidly increase when the storage $\mathrm{O}_{2}$ level was lower than $1 \mathrm{kPa}$. The model confirmed that 455 picking time, and fruit size are important criteria affecting the risk of fermentation during CA 456 storage. 
The authors thank the Research Council of KU Leuven (OT 08/023 \& 12/055), the Flanders Fund for Scientific Research (project G.0645.13), and the Institute for the Promotion of Innovation by Science and Technology in Flanders (project IWT-120033 'TomFood') for financial support. This research was carried out in the context of the European COST Action FA1106 ('QualiFruit'). 3D imaging was achieved with the support of the Hercules Foundation (AKUL001(HER/09/016)) and a beamtime grant of the ESRF, Grenoble, France (experiment number MA222).

\section{References}

Bosch, V., Cilla, A., García-Llatas, G., Gilabert, V., Boix, R., Alegría, A., 2013. Kinetics of ascorbic acid degradation in fruit-based infant foods during storage. Journal of Food Engineering 116, 298-303. doi:10.1016/j.jfoodeng.2012.12.003

Bulens, I., Van de Poel, B., Hertog, M.L.A.T.M., De Proft, M.P., Geeraerd, A.H., Nicolai, B.M., 2012. Influence of harvest time and 1-MCP application on postharvest ripening and ethylene biosynthesis of "Jonagold" apple. Postharvest Biology and Technology 72, 11-19. doi:10.1016/j.postharvbio.2012.05.002

Datta, A.K., 2008. Status of Physics-Based Models in the Design of Food Products, Processes, and Equipment. Comprehensive Reviews in Food Science and Food Safety 7, 121-129. doi:10.1111/j.1541-4337.2007.00030.x

Delele, M.A., Nicolaï, B., Verboven, P., Verlinden, B.E., 2013. Storage of respiratory produce. US Patent 20,130,013,099, 2013; EP Patent 2,547,213, 2013; WO Patent 2,011,113,915, 2011.

Feyissa, A.H., Gernaey, K. V., Adler-Nissen, J., 2012. Uncertainty and sensitivity analysis: Mathematical model of coupled heat and mass transfer for a contact baking process. Journal of Food Engineering 109, 281-290. doi:10.1016/j.jfoodeng.2011.09.012

Franck, C., Lammertyn, J., Ho, Q.T., Verboven, P., Verlinden, B., Nicolaï, B.M., 2007. Browning disorders in pear fruit. Postharvest Biology and Technology 43, 1-13.

Fukuda, S., Yasunaga, E., Nagle, M., Yuge, K., Sardsud, V., Spreer, W., Müller, J., 2014. Modelling the relationship between peel colour and the quality of fresh mango fruit using 
Random Forests. Journal of Food Engineering 131, 7-17. doi:10.1016/j.jfoodeng.2014.01.007

Gasser, F., Eppler, T., Naunheim, W., Gabioud, S., Hoehn, E., 2008. Control of the critical oxygen level during dynamic CA storage of apples by monitoring respiration as well as chlorophyll fluorescence. ISHS Acta Horticulturae 796, 69-76.

Goñi, S.M., Purlis, E., Salvadori, V.O., 2008. Geometry modelling of food materials from magnetic resonance imaging. Journal of Food Engineering 88, 561-567. doi:10.1016/j.jfoodeng.2008.03.020

Herremans, E., Verboven, P., Bongaers, E., Estrade, P., Verlinden, B.E., Wevers, M., Hertog, M.L.A.T.M., Nicolai, B.M., 2013a. Characterisation of "Braeburn" browning disorder by means of X-ray micro-CT. Postharvest Biology and Technology 75, 114-124. doi:10.1016/j.postharvbio.2012.08.008

Herremans, E., Verboven, P., Defraeye, T., Rogge, S., Ho, Q.T., Hertog, M.L. a. T.M., Verlinden, B.E., Bongaers, E., Wevers, M., Nicolai, B.M., 2013b. X-ray CT for quantitative food microstructure engineering: The apple case. Nuclear Instruments and Methods in Physics Research Section B: Beam Interactions with Materials and Atoms. doi:10.1016/j.nimb.2013.07.035

Hertog, M.L.A.T.M., Lammertyn, J., Scheerlinck, N., Nicolaï, B.M., 2007. The impact of biological variation on postharvest behaviour: The case of dynamic temperature conditions. Postharvest Biology and Technology 43, 183-192. doi:10.1016/j.postharvbio.2006.09.014

Hertog, M.L.A.T.M., Peppelenbos, H.W., Evelo, R.G., Tijskens, L.M.M., 1998. A dynamic and generic model of gas exchange of respiring produce: the effects of oxygen, carbon dioxide and temperature. Postharvest Biology and Technology 14, 335-349. doi:10.1016/S09255214(98)00058-1

Ho, Q.T., Verboven, P., Mebatsion, H.K., Verlinden, B.E., Vandewalle, S., Nicolaï, B.M., 2009. Microscale mechanisms of gas exchange in fruit tissue. The New phytologist 182, 163-74. doi:10.1111/j.1469-8137.2008.02732.x

Ho, Q.T., Verboven, P., Verlinden, B.E., Herremans, E., Wevers, M., Carmeliet, J., Nicolaï, B.M., 2011. A three-dimensional multiscale model for gas exchange in fruit. Plant Physiology 155, 1158-68. doi:10.1104/pp.110.169391

Ho, Q.T., Verboven, P., Verlinden, B.E., Lammertyn, J., Vandewalle, S., Nicolaï, B.M., 2008. A continuum model for metabolic gas exchange in pear fruit. PLoS Computational Biology 4 , e1000023. doi:10.1371/journal.pcbi.1000023 
Ho, Q.T., Verboven, P., Verlinden, B.E., Nicolaï, B.M., 2010a. A model for gas transport in pear fruit at multiple scales. Journal of Experimental Botany 61, 2071-81. doi:10.1093/jxb/erq026

Ho, Q.T., Verboven, P., Verlinden, B.E., Schenk, A., Delele, M.A., Rolletschek, H., Vercammen, J., Nicolaï, B.M., 2010b. Genotype effects on internal gas gradients in apple fruit. Journal of Experimental Botany 61, 2745-55. doi:10.1093/jxb/erq108

Ho, Q.T., Verboven, P., Verlinden, B.E., Schenk, A., Nicolaï, B.M., 2013. Controlled atmosphere storage may lead to local ATP deficiency in apple. Postharvest Biology and Technology 78, 103-112. doi:10.1016/j.postharvbio.2012.12.014

Ho, Q.T., Verlinden, B.E., Verboven, P., Vandewalle, S., Nicolaï, B.M., 2006. A permeationdiffusion-reaction model of gas transport in cellular tissue of plant materials. Journal of Experimental Botany 57, 4215-24. doi:10.1093/jxb/erl198

Lammertyn, J., 2001. Comparative study of the $\mathrm{O}_{2}, \mathrm{CO}_{2}$ and temperature effect on respiration between "Conference" pear cell protoplasts in suspension and intact pears. Journal of Experimental Botany 52, 1769-1777. doi:10.1093/jexbot/52.362.1769

Lammertyn, J., Aerts, M., Verlinden, B.E., Schotsmans, W., Nicolaï, B.M., 2000. Logistic regression analysis of factors influencing core breakdown in "Conference" pears. Postharvest Biology and Technology 20, 25-37. doi:10.1016/S0925-5214(00)00114-9

Lammertyn, J., Scheerlinck, N., Jancsók, P., Verlinden, B.., Nicolaï, B.., 2003. A respirationdiffusion model for "Conference" pears I: model development and validation. Postharvest Biology and Technology 30, 29-42. doi:10.1016/S0925-5214(03)00061-9

Lammertyn, J., Scheerlinck, N., Verlinden, B.., Schotsmans, W., M. Nicolaï, B., 2001. Simultaneous determination of oxygen diffusivity and respiration in pear skin and tissue. Postharvest Biology and Technology 23, 93-104. doi:10.1016/S0925-5214(01)00113-2

Li, L., Guan, J., He, J., 2011. Effects of harvesting time on fruit quality and internal browning of "Wonhuwang" pear during cold storage. Frontiers of Agriculture in China 5, 247-250. doi:10.1007/s11703-011-1093-3

Mannapperuma, J.D., Singh, R.P., Montero, M.E., 1991. Simultaneous gas diffusion and chemical reaction in foods stored in modified atmospheres. Journal of Food Engineering 14, 167-183. doi:10.1016/0260-8774(91)90006-E

Masia, A., 2003. Physiological effects of oxidative stress in relation to ethylene in postharvest produce, in: Hodges D.M. (Ed.), Postharvest Oxidative Stress in Horticultural Crops. Food Products Press, New York, pp. 165-197. 
Mebatsion, H.K., Boudon, F., Godin, C., Pradal, C., Génard, M., Goz-Bac, C., Bertin, N., 2011. A novel profile based model for virtual representation of quasi-symmetric plant organs. Computers and Electronics in Agriculture 75, 113-124. doi:10.1016/j.compag.2010.10.006

Millar, A.H., Bergersen, F.J., Day, D.A., 1994. Oxygen affinity of terminal oxidases in soybean mitochondria. Plant Physiology and Biochemistry 32, 847-852.

Nicolaï, B.M., Egea, J.A., Scheerlinck, N., Banga, J.R., Datta, A.K., 2011. Fuzzy finite element analysis of heat conduction problems with uncertain parameters. Journal of Food Engineering 103, 38-46. doi:10.1016/j.jfoodeng.2010.09.017

Pedreschi, R., Franck, C., Lammertyn, J., Erban, A., Kopka, J., Hertog, M., Verlinden, B., Nicolaï, B., 2009. Metabolic profiling of "Conference" pears under low oxygen stress. Postharvest Biology and Technology 51,123-130. doi:10.1016/j.postharvbio.2008.05.019

Peppelenbos, H.W., Oosterhaven, J., 1998. A theoretical approach on the role of fermentation in harvested plant products. Acta Horticulturae 464, 381-386.

Peppelenbos, H.W., van't Leven, J., 1996. Evaluation of four types of inhibition for modelling the influence of carbon dioxide on oxygen consumption of fruits and vegetables. Postharvest Biology and Technology 7, 27-40. doi:10.1016/0925-5214(96)80995-1

Perrot, N., Trelea, I.C., Baudrit, C., Trystram, G., Bourgine, P., 2011. Modelling and analysis of complex food systems: State of the art and new trends. Trends in Food Science \& Technology 22, 304-314. doi:10.1016/j.tifs.2011.03.008

Pinheiro, J., Alegria, C., Abreu, M., Gonçalves, E.M., Silva, C.L.M., 2013. Kinetics of changes in the physical quality parameters of fresh tomato fruits (Solanum lycopersicum, cv. "Zinac") during storage. Journal of Food Engineering 114, 338-345. doi:10.1016/j.jfoodeng.2012.08.024

Prange, R.K., DeLong, J.M., Wright, A.H., 2011. Storage of pears using dynamic controlledatmosphere (DCA), a non-chemical method. Acta Horticulturae 909, 707-717.

Rawsthorne, S., Larue, T.A., 1986. Metabolism under Microaerobic Conditions of Mitochondria from Cowpea Nodules. Plant Physiology 81, 1097-1102. doi:10.1104/pp.81.4.1097

Rogge, S., Beyene, S.D., Herremans, E., Hertog, M.L., Defraeye, T., Verboven, P., Nicolai, B.M., 2013. A Geometrical Model Generator for Quasi-Axisymmetric Biological Products. Food and Bioprocess Technology 7, 1783-1792. doi:10.1007/s11947-013-1169-6

Rogge, S., Defraeye, T., Herremans, E., Verboven, P., Nicolaï, B.M., 2015. A 3D contour based geometrical model generator for complex-shaped horticultural products. Journal of Food Engineering 157, 24-32. doi:10.1016/j.jfoodeng.2015.02.006 
Saquet, A.A., Streif, J., Bangerth, F., 2003. Energy metabolism and membrane lipid alterations in relation to brown heart development in "Conference" pears during delayed controlled atmosphere storage. Postharvest Biology and Technology 30, 123-132. doi:10.1016/S09255214(03)00099-1

Scheerlinck, N., Verboven, P., Stigter, J.D., De Baerdemaeker, J., Van Impe, J.F., Nicolai, B.M., 2001. A variance propagation algorithm for stochastic heat and mass transfer problems in food processes. International Journal for Numerical Methods in Engineering 51, 961-983. doi: $10.1002 /$ nme. 202

Schotsmans, W., Verlinden, B.., Lammertyn, J., Nicolaï, B.., 2003. Simultaneous measurement of oxygen and carbon dioxide diffusivity in pear fruit tissue. Postharvest Biology and Technology 29, 155-166. doi:10.1016/S0925-5214(02)00251-X

Schotsmans, W., Verlinden, B.E., Lammertyn, J., Peirs, A., Jancsók, P.T., Scheerlinck, N., Nicolaï, B.M., 2002. Factors affecting skin resistance measurements in pipfruit. Postharvest Biology and Technology 25, 169-179. doi:10.1016/S0925-5214(01)00170-3

Serment-Moreno, V., Deng, K., Wu, X., Su, Y.-C., Fuentes, C., Antonio Torres, J., WeltiChanes, J., 2015. Monte Carlo analysis of the product handling and high-pressure treatment effects on the Vibrio vulnificus risk to raw oysters consumers. Journal of Food Engineering 144, 86-92. doi:10.1016/j.jfoodeng.2014.07.014

Streif, J., Saquet, A., Xuan, H., 2003. CA-related disorders of apples and pears. Acta Horticulturae 600, 223-230.

Taiz, L., Zeiger, E., 1993. Plant physiology. The Benjamin/Cummings Publishing Company Inc , California.

Torrez Irigoyen, R.M., Goñi, S.M., Giner, S.A., 2014. Drying-toasting kinetics of presoaked soybean. A mathematical model considering variable diffusivity, shrinkage and coupled heat transfer. Journal of Food Engineering 142, 70-79. doi:10.1016/j.jfoodeng.2014.06.002

Veltman, R.., Lenthéric, I., Van der Plas, L.H.., Peppelenbos, H.., 2003a. Internal browning in pear fruit (Pyrus communis L. cv Conference) may be a result of a limited availability of energy and antioxidants. Postharvest Biology and Technology 28, 295-302. doi:10.1016/S0925-5214(02)00198-9

Veltman, R.., Verschoor, J.., van Dugteren, J.H.R., 2003b. Dynamic control system (DCS) for apples (Malus domestica Borkh. cv "Elstar"): optimal quality through storage based on product response. Postharvest Biology and Technology 27, 79-86. doi:10.1016/S09255214(02)00186-2

Veltman, R.H., Sanders, M.G., Persijn, S.T., Pemppelenbos, H.W., Oosterhaven, J., 1999. Decreased ascorbic acid levels and brown core development in pears (Pyrus communis L. 
624

625

626

627

628

629

630

631

632

633

634

635

636

637

638

639

640

641

642

643

644

645

646

647

cv. Conference). Physiologia Plantarum 107, 39-45. doi:10.1034/j.13993054.1999.100106.x

Verboven, P., Herremans, E., Borisjuk, L., Helfen, L., Ho, Q.T., Tschiersch, H., Fuchs, J., Nicolaï, B.M., Rolletschek, H., 2013. Void space inside the developing seed of Brassica napus and the modelling of its function. The New phytologist 199, 936-47. doi:10.1111/nph.12342

Verboven, P., Kerckhofs, G., Mebatsion, H.K., Ho, Q.T., Temst, K., Wevers, M., Cloetens, P., Nicolaï, B.M., 2008. Three-dimensional gas exchange pathways in pome fruit characterized by synchrotron x-ray computed tomography. Plant Physiology 147, 518-27. doi:10.1104/pp.108.118935

Verboven, P., Pedersen, O., Herremans, E., Ho, Q.T., Nicolaï, B.M., Colmer, T.D., Teakle, N., 2012. Root aeration via aerenchymatous phellem: three-dimensional micro-imaging and radial O2 profiles in Melilotus siculus. The New Phytologist 193, 420-31. doi:10.1111/j.1469-8137.2011.03934.x

Verlinden, B.E., de Jager, A., Lammertyn, J., Schotsmans, W., Nicolai, B.M., 2002. PHPostharvest Technology: Effect of harvest and delaying controlled atmosphere storage conditions on core breakdown incidence in 'Conference' pears. Biosystems Engineering 83, 339-347. doi:10.1006/bioe.2002.0127

Zerbini, P.E., Rizzolo, A., 2002. Loss of ascorbic acid during storage of Conference pears in relation to the appearance of brown heart. Journal of the Science of Food and Agriculture $82,1007-1013$.

Zhou, Y., Pan, X., Qu, H., Underhill, S.J.R., 2014. Low temperature alters plasma membrane lipid composition and ATPase activity of pineapple fruit during blackheart development. Journal of bioenergetics and biomembranes 46, 59-69. doi:10.1007/s10863-013-9538-4 
649

(a)
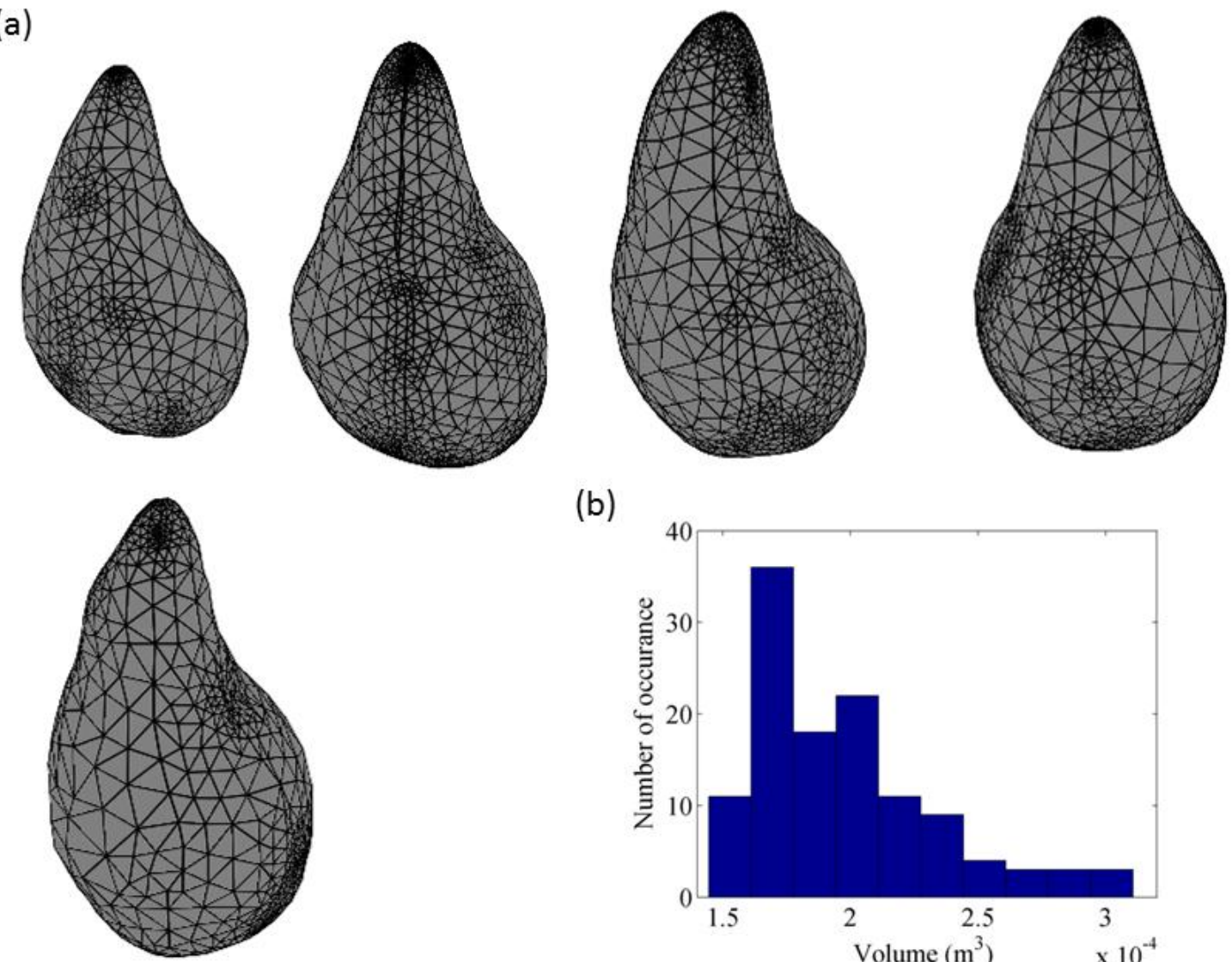

(b)

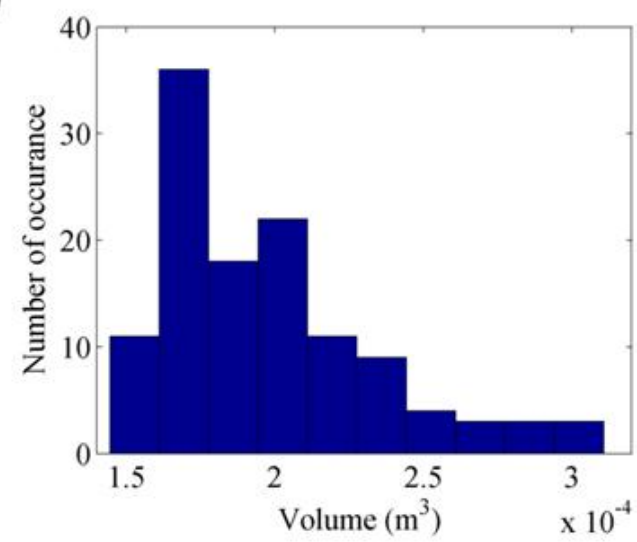

650

651 Fig. 1 Stochastic shape model of pear fruit: (a) Samples of generated geometrical models of

652 Conference pear. (b) Distribution of volume of pear fruit obtained from 120 generated 653 geometrical models.

654 
(a)

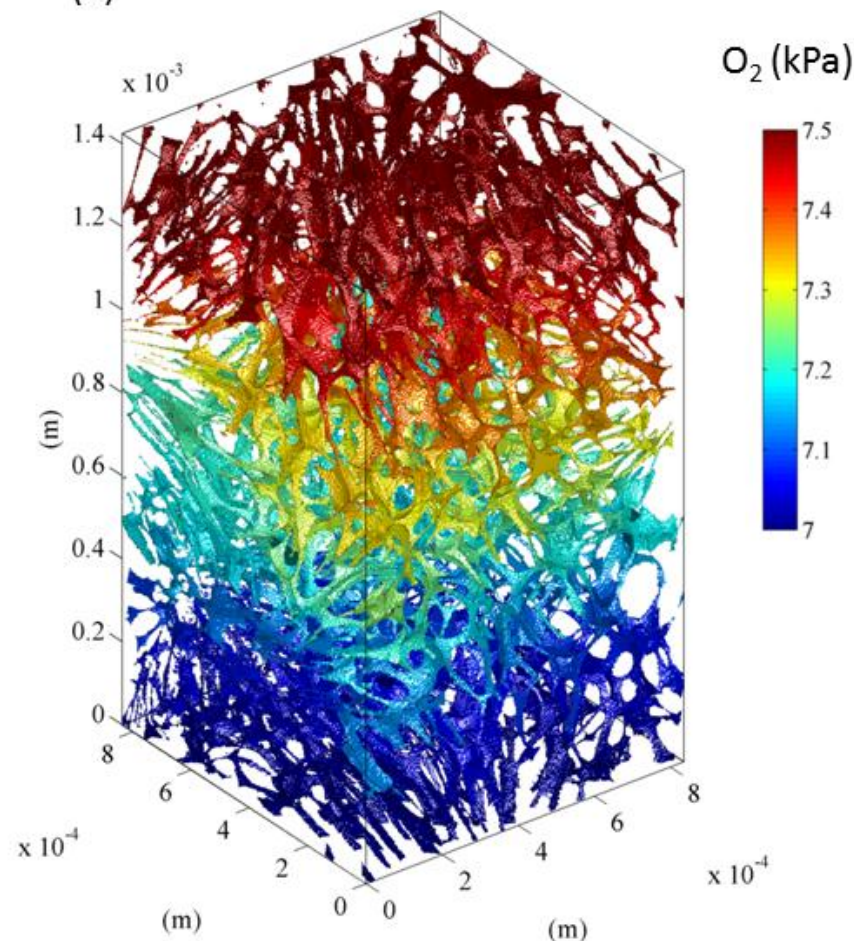

(d)

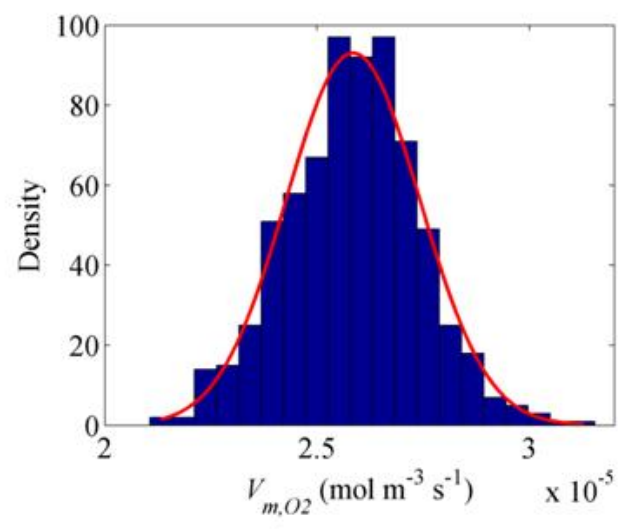

(b)

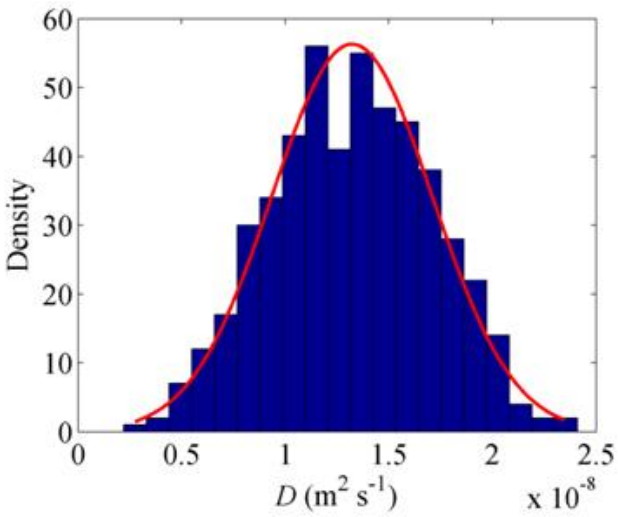

(c)

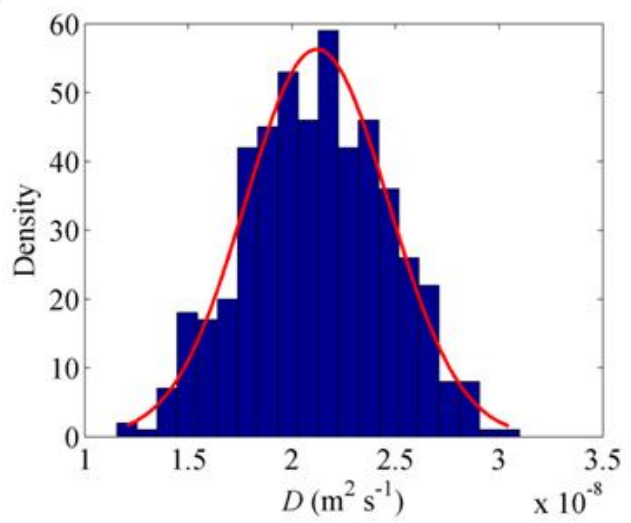

(e)

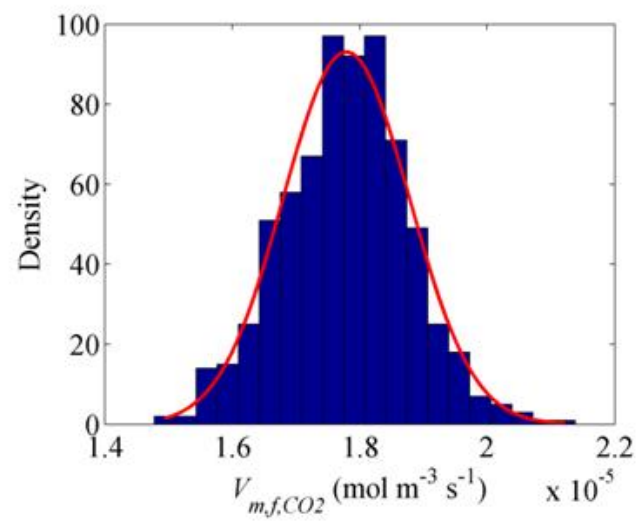

656

657 Fig. 2. Stochastic properties of pear fruit: (a) Simulated $\mathrm{O}_{2}$ distribution in microstructure of

658 cortex tissue of pear fruit. The color represents the $\mathrm{O}_{2}$ concentration in the pores $\left(\mathrm{mol} \mathrm{m}^{-3}\right)$ for a 
659 gradient imposed over the sample. The flux through the sample is then calculated from which the 660 diffusivity is obtained. (b) and (c) Probability density distributions of the overall apparent 661 diffusivity of $\mathrm{O}_{2}$ and $\mathrm{CO}_{2}$, respectively, based on 500 Monte Carlo simulations using the random 662 microstructures. (d) and (e) Probability density distributions of the maximal $\mathrm{O}_{2}$ consumption rate $663 V_{m, o_{2}}$ and the maximal $\mathrm{CO}_{2}$ production rate $V_{m, f, c O_{2}}$ generated from measured data and standard 664 errors.

665 
(a)

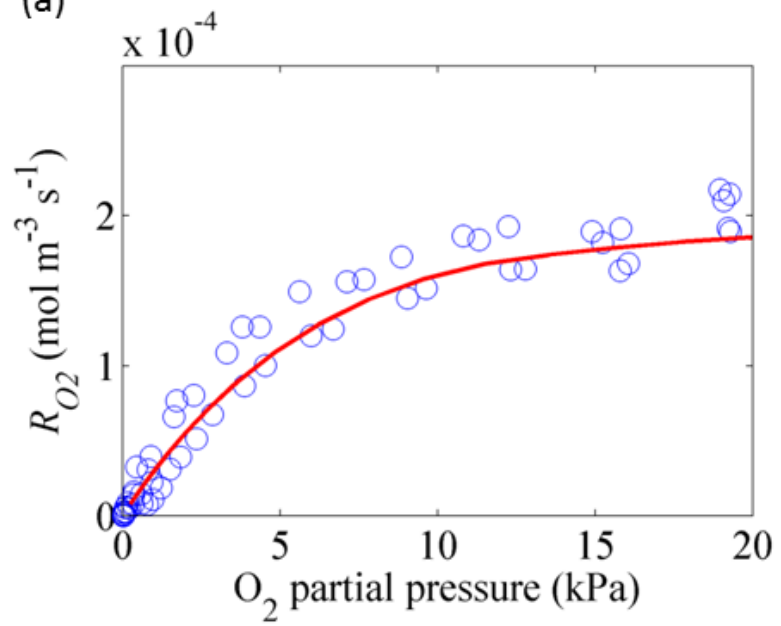

(c) $\times 10^{-4}$

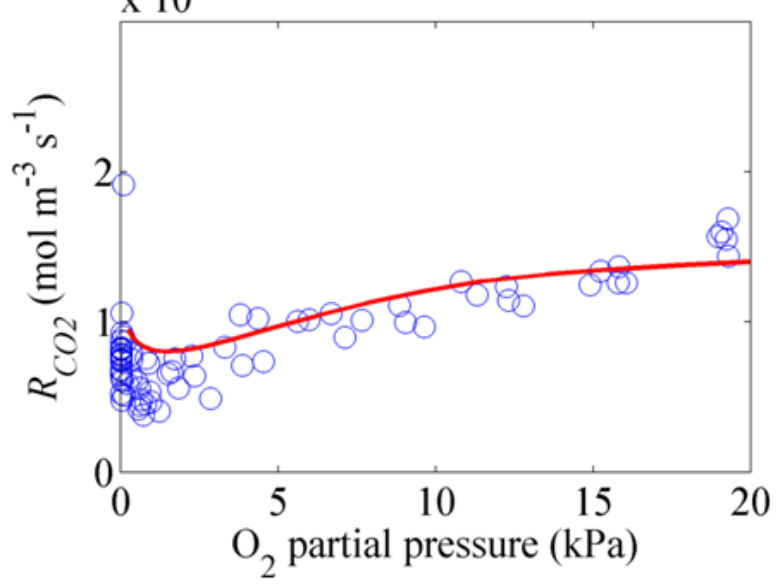

(b)
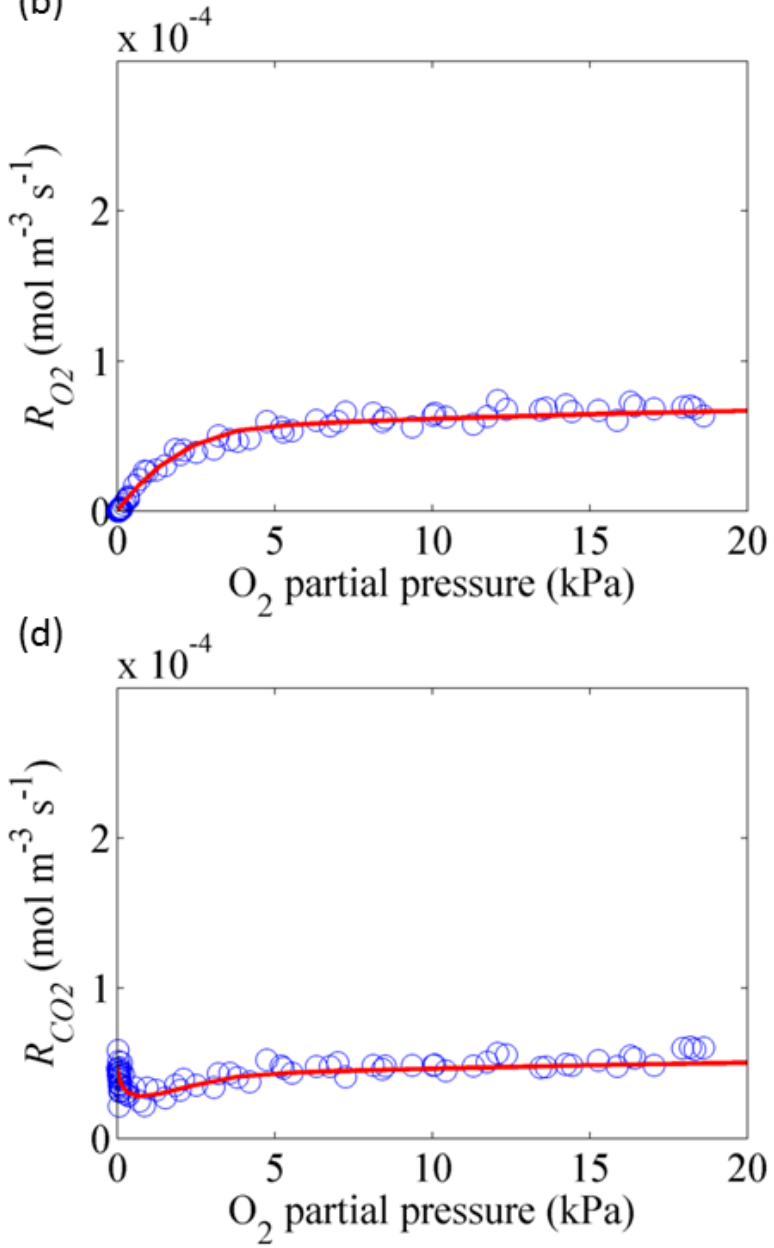

667

668 Fig. 3 Validation of the diffusion reaction model. $\mathrm{O}_{2}$ consumption rate $\left(R_{O 2}\right)$ and $\mathrm{CO}_{2}$ production

669 rate $\left(R_{\mathrm{CO} 2}\right)$ of intact pear fruit as a function of the $\mathrm{O}_{2}$ concentration at $20^{\circ} \mathrm{C}(\mathrm{a}, \mathrm{c})$ and $10^{\circ} \mathrm{C}(\mathrm{b}, \mathrm{d})$.

670 Symbols (o) indicate measurements and solid lines (-) correspond to simulations.

671 

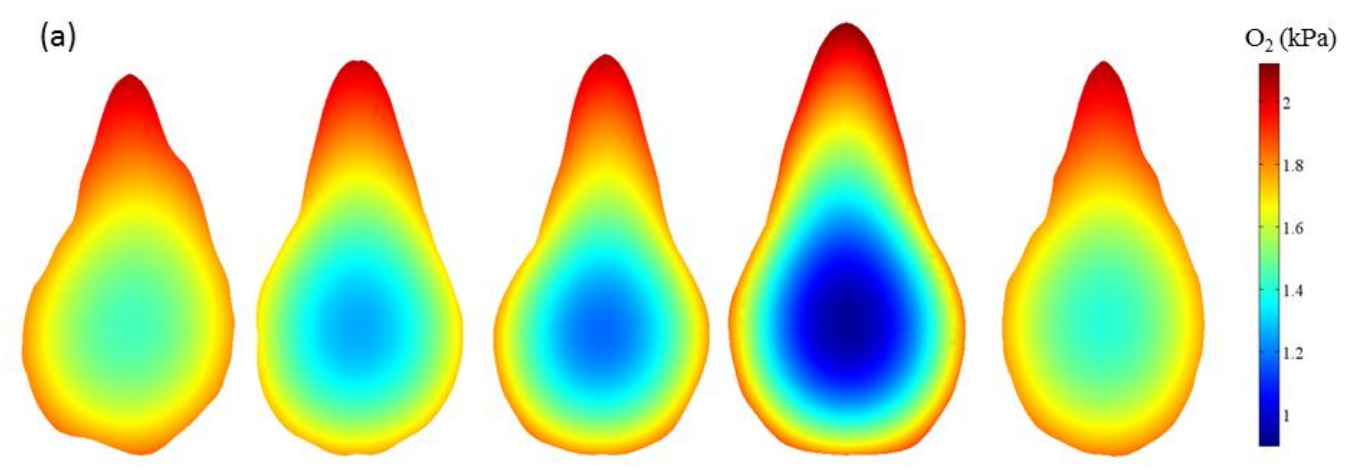

672
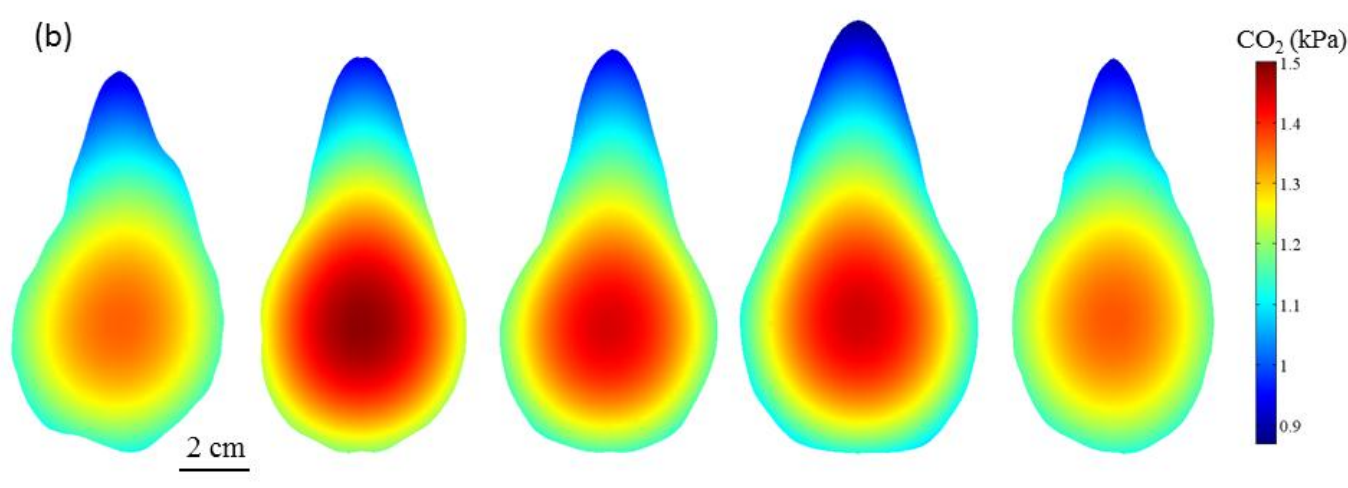

$\begin{array}{cccccc}\begin{array}{c}D_{\mathrm{O}_{2}} \\ \left(10^{-9} \mathrm{~m}^{2} \mathrm{~s}^{-1}\right)\end{array} & 16.9 & 15.2 & 10.4 & 6.89 & 16.5 \\ D_{\mathrm{CO}_{2}} & 23.7 & 22.4 & 19.1 & 16.0 & 25.0 \\ \left(10^{-9} \mathrm{~m}^{2} \mathrm{~s}^{-1}\right) & & & & 1.85 \\ V_{m, O_{2}} & 1.90 & 2.16 & 1.92 & 1.61 & 1.77 \\ \left(10^{-5} \mathrm{~mol} \mathrm{~m}^{-3} \mathrm{~s}^{-1}\right) & & & & 1.49 & \\ V_{m, f, O_{2}} & 1.83 & 2.14 & 1.85 & & \end{array}$

674

675 Fig. 4. Examples of simulated $\mathrm{O}_{2}$ and $\mathrm{CO}_{2}$ partial pressure distributions in different intact pears 676 (vertical cross sections of the 3D pear model) at commercial CA conditions of $2.5 \mathrm{kPa} \mathrm{O}_{2}, 0.7$

$677 \mathrm{kPa} \mathrm{CO}$ and $-1{ }^{\circ} \mathrm{C}$. The variation of shape, cortex diffusivities and respiration rate was taken 678 into account and described in Fig. $1 \& 2$. Used parameters are given below the figure. The color 679 indicates gas partial pressure $(\mathrm{kPa})$. 
(a)

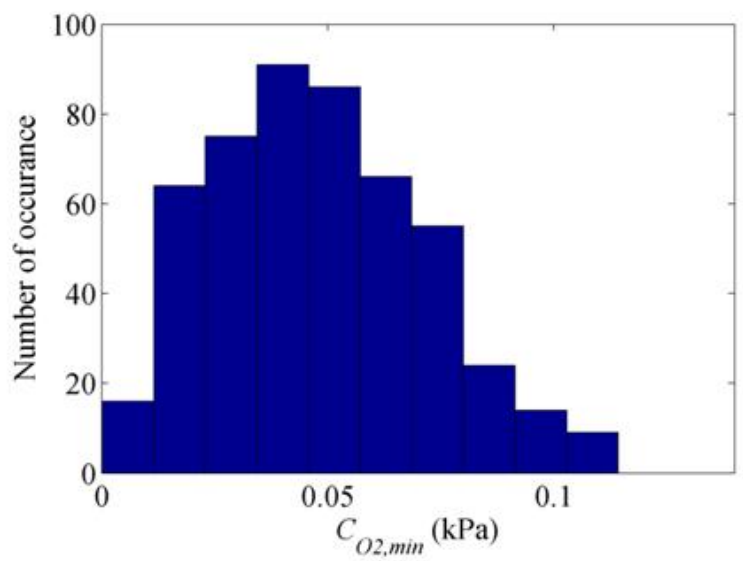

(c)

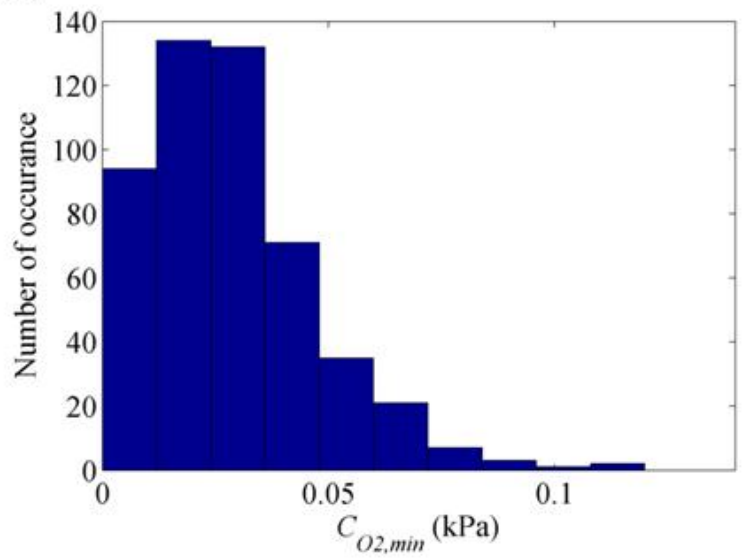

(e)

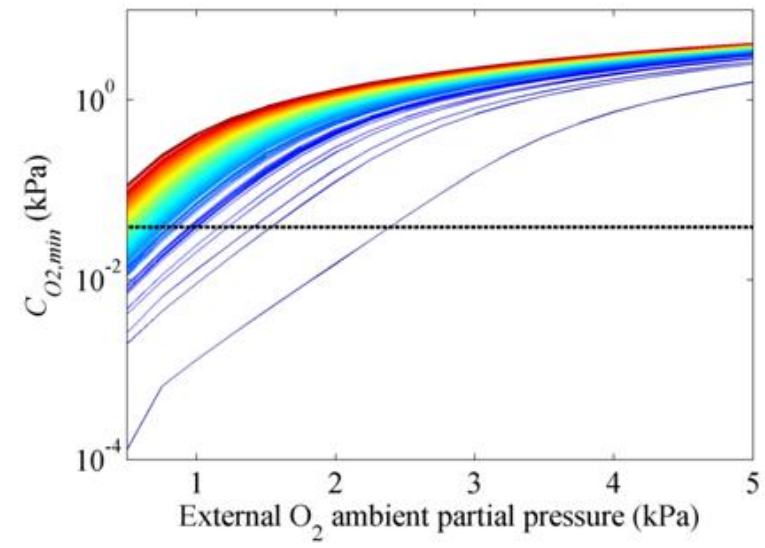

(b)

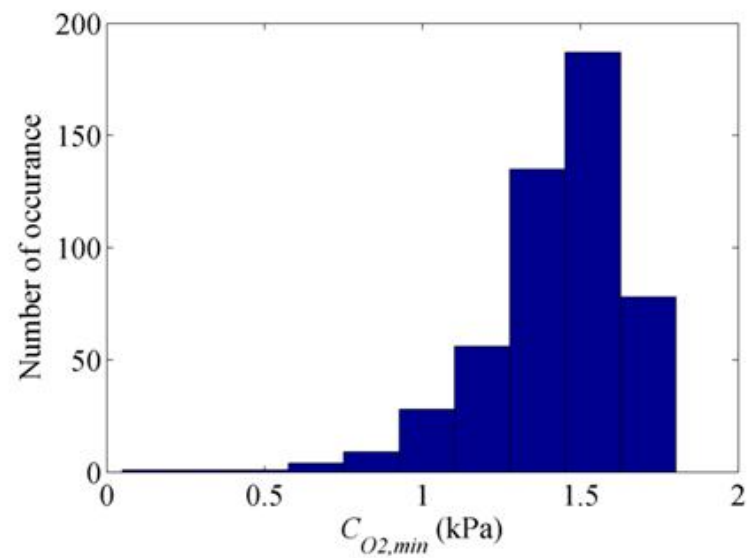

(d)

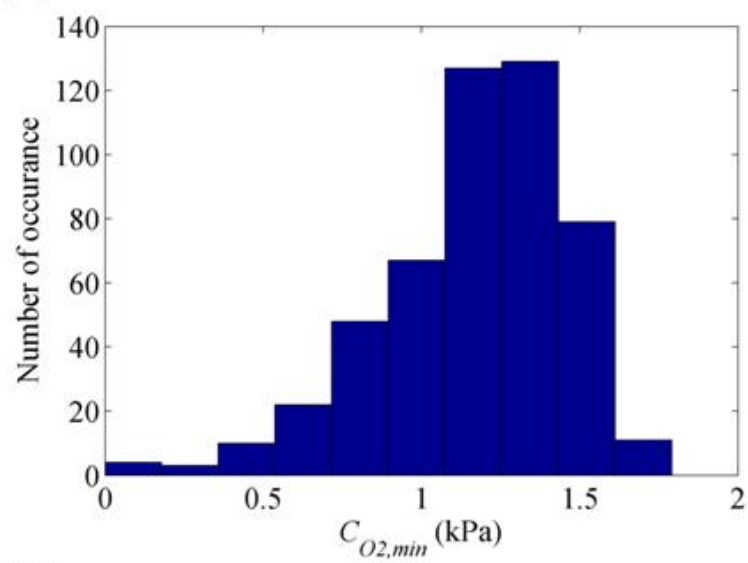

(f)

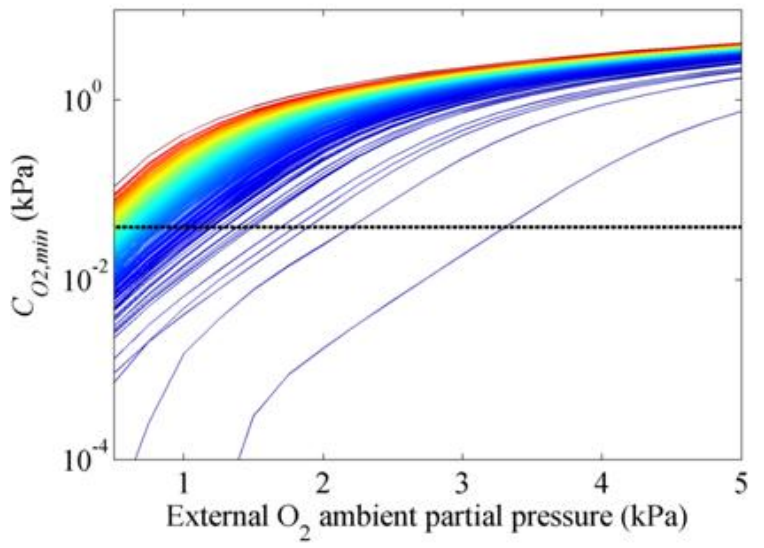

681 
682 Fig. 5. Histogram of $C_{O_{2}, \mathrm{~min}}$ at low external $\mathrm{O}_{2}$ conditions computed with Monte Carlo 683 simulations at $-1{ }^{\circ} \mathrm{C}$ for optimally picked pear (a \& b) and late picked pear (c \& d). (a) and (c) 684 are simulation results at $0.5 \mathrm{kPa} \mathrm{O}_{2}$ while (b) and (d) are simulation results at $2.5 \mathrm{kPa} \mathrm{O}_{2}$. (e) and 685 (f) Predicted $C_{O_{2}, \text { min }}$ as a function of the ambient $\mathrm{O}_{2}$ partial pressure at $0^{\circ} \mathrm{C}$. Simulations take 686 variations in respiration capacity, diffusivity and shape of pear fruit into account. The horizontal 687 dashed (- -) line indicates the critical $C_{\mathrm{O}_{2}}^{*}$. (e) and (f) represent simulations for the optimal 688 picked pear and late picked pear, respectively. 
(a)

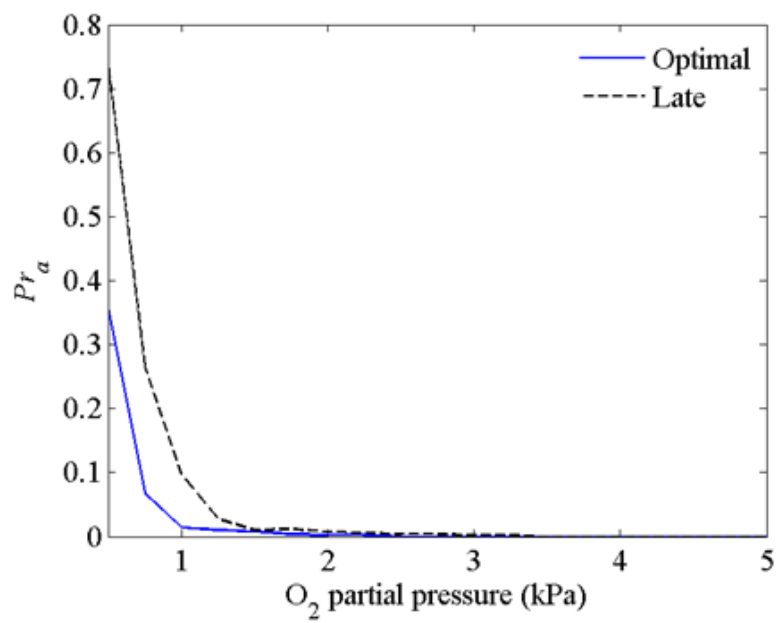

(b)

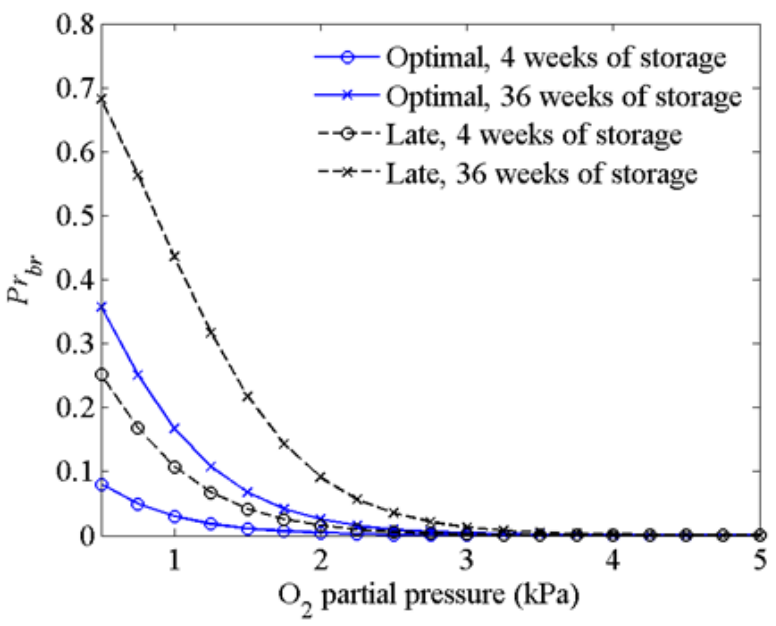

692

693 Fig. 6 Probability of fermentation (a) and browning disorder (b) of pear as a function of $\mathrm{O}_{2}$ level.

694

(a) Probability of fermentation $\left(\operatorname{Pr}_{a}\right)$ of optimally and late picked fruit predicted by the gas

695 exchange model. (b) Probability of browning disorder of optimal and late picked fruit from 4 to 36 weeks predicted by the logistic regression model described by Verlinden et al. (2002).

697 

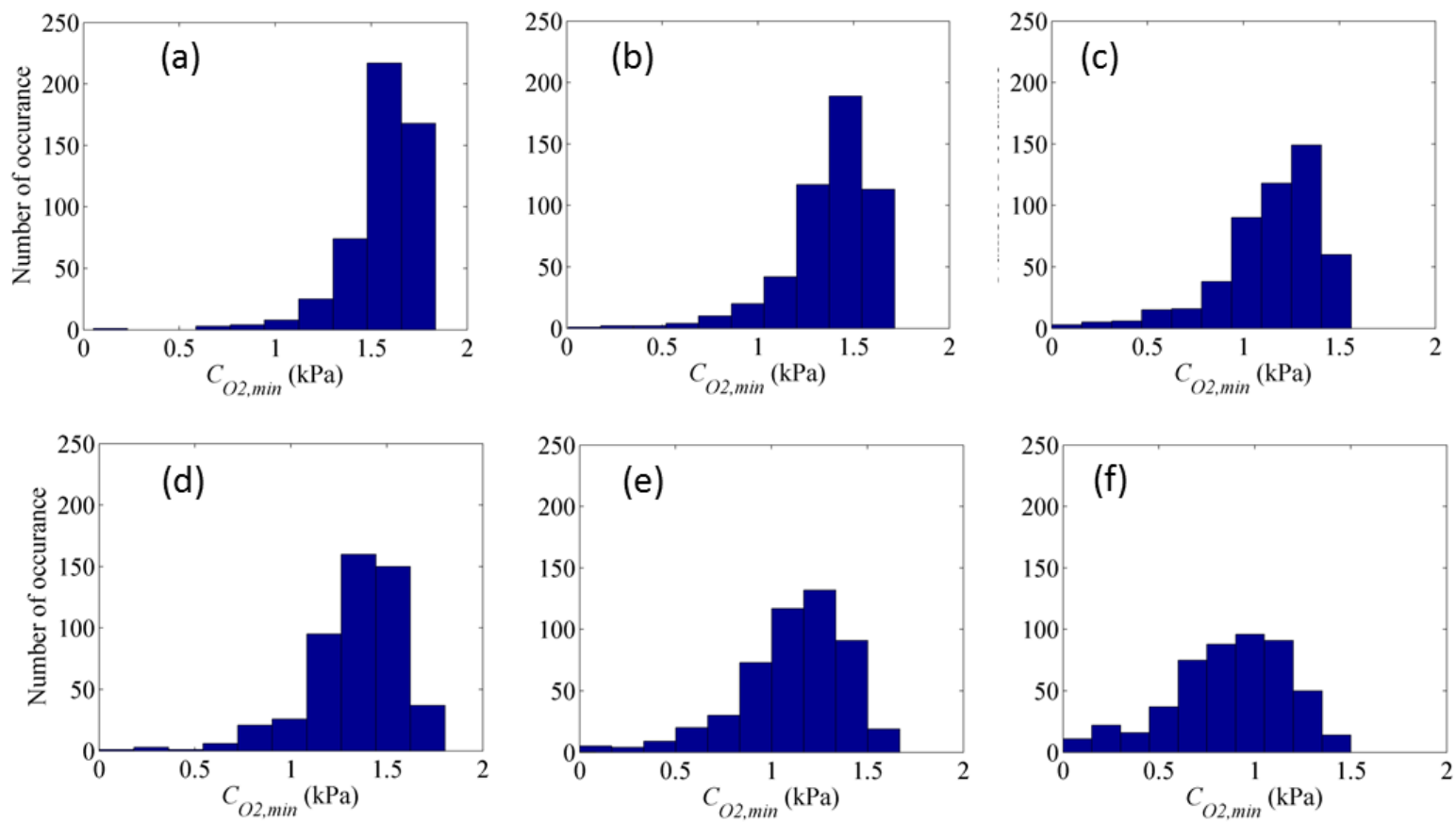

701 Fig. 7 Effect of fruit volume on the probability distribution of low oxygen concentration in pear.

702 Histograms of $C_{O_{2}, \text { in }}$ are shown for increasing fruit volumes equal to $1.44 \times 10^{-4}$ (a, d), $2.11 \times 10^{-4}$ $703(\mathrm{~b}, \mathrm{e})$ and $3.0 \times 10^{-4} \mathrm{~m}^{3}(\mathrm{c}, \mathrm{f})$, respectively. Simulations were carried out at $2.5 \mathrm{kPa} \mathrm{O}_{2}, 0.7 \mathrm{kPa}$ $704 \mathrm{CO}_{2}$ and $-1{ }^{\circ} \mathrm{C}$. (a), (b) and (c): optimally picked pear; (d), (e) and (f): late picked pear. 
707 Table 1 Parameters of macroscale gas transport model

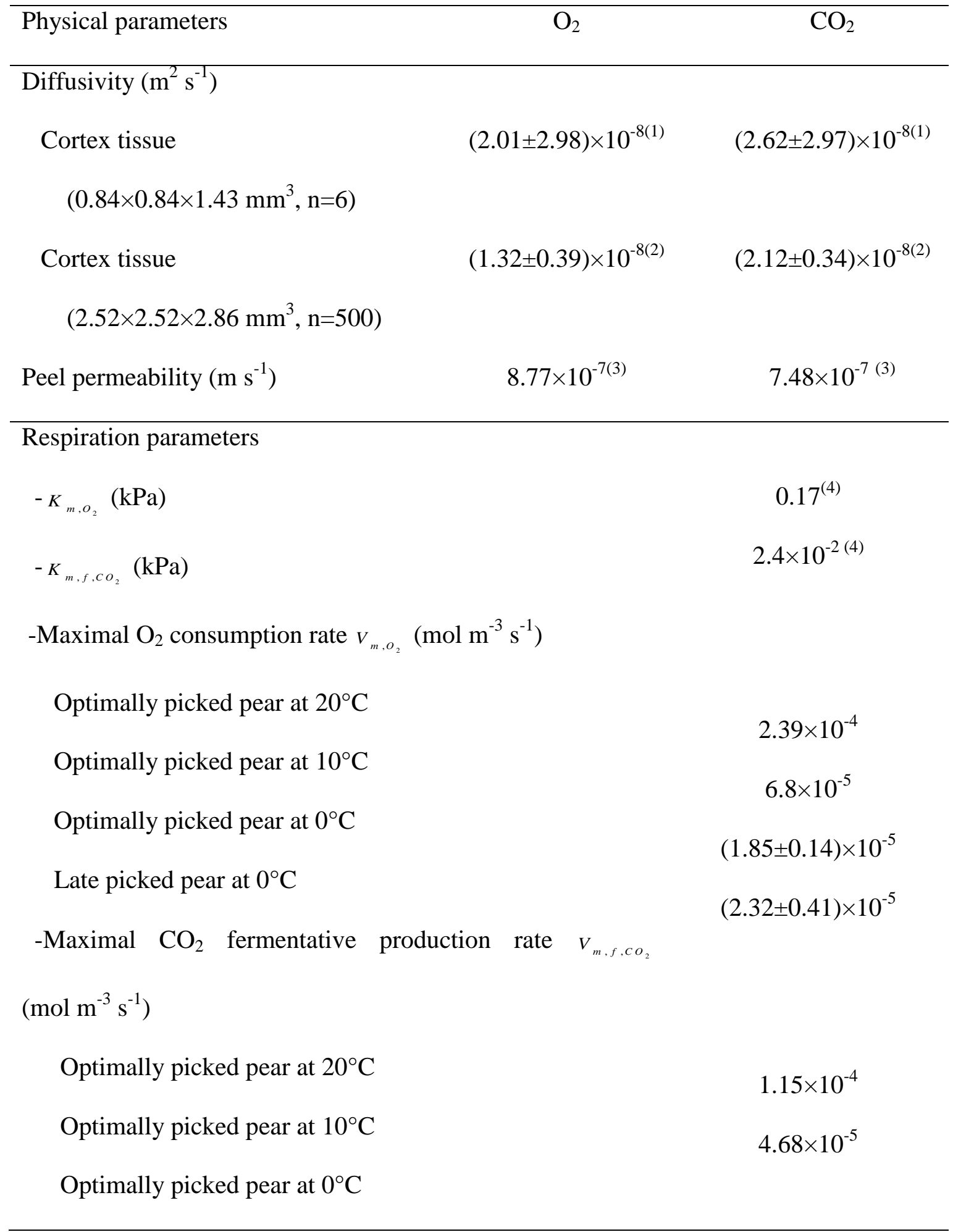


Late picked pear at $0^{\circ} \mathrm{C}$ $(1.78 \pm 0.17) \times 10^{-5}$

$(1.90 \pm 0.49) \times 10^{-5}$

$708{ }^{(1)}$ Computed from microscale model

$709{ }^{(2)}$ Apparent diffusivity of stochastic simulations for a larger sample containing random effective 710 diffusivities computed from simulated 3D microscale.

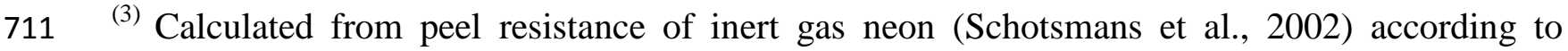
712 Graham's law.

$713{ }^{(4)}$ Ho et al. (2013). 